\title{
Transactions
}

Cite this: Dalton Trans., 2011, 40, 9899

wWW.rsc.org/dalton

PAPER

\section{Syntheses, crystal structures, reactivity, and photochemistry of gold(III) bromides bearing $\mathbf{N}$-heterocyclic carbenes $\uparrow$}

\author{
Christa Hirtenlehner, ${ }^{a}$ Charlotte Krims, ${ }^{a}$ Johanna Hölbling, ${ }^{a}$ Manuela List, ${ }^{b}$ Manfred Zabel,${ }^{c}$ Michel Fleck, ${ }^{d}$ \\ Raphael J. F. Berger, ${ }^{e}$ Wolfgang Schoefberger ${ }^{a}$ and Uwe Monkowius ${ }^{\star a}$
}

Received 21st June 2011, Accepted 20th July 2011

DOI: $10.1039 / c 1 d t 11175 b$

Gold(I) complexes bearing N-heterocyclic carbenes (NHC) of the type $(\mathrm{NHC}) \mathrm{AuBr}(\mathbf{3 a} / \mathbf{3 b})[\mathrm{NHC}=$ 1-methyl-3-benzylimidazol-2-ylidene (= MeBnIm), and 1,3-dibenzylimidazol-2-ylidene $\left.\left(=\mathrm{Bn}_{2} \mathrm{Im}\right)\right]$ are prepared by transmetallation reactions of (tht) $\mathrm{AuBr}$ (tht $=$ tetrahydrothiophene) and (NHC)AgBr $(\mathbf{2 a} / \mathbf{2 b})$. The homoleptic, ionic complexes $\left[(\mathrm{NHC})_{2} \mathrm{Au}\right] \mathrm{Br}(\mathbf{6 a} / \mathbf{6 b})$ are synthesized by the reaction with free carbene. Successive oxidation of $\mathbf{3 a} / \mathbf{3 b}$ and $\mathbf{6 a} / \mathbf{6} \mathbf{b}$ with bromine gave the respective (NHC) $\mathrm{AuBr}_{3}$ $(\mathbf{4 a} / \mathbf{4 b})$ and $\left[(\mathrm{NHC})_{2} \mathrm{AuBr}_{2}\right] \mathrm{Br}(\mathbf{7} \mathbf{a} / \mathbf{7 b})$ in good overall yields as yellow powders. All complexes were characterized by NMR spectroscopy, mass spectrometry, elemental analysis and single crystal X-ray diffraction. Reactions of the $\mathrm{Au}(\mathrm{III})$ complexes towards anionic ligands like carboxylates, phenolates and thiophenolates were investigated and result in a complete or partial reduction to a Au(I) complex. Irradiation of the $\mathrm{Au}(\mathrm{III})$ complexes with $\mathrm{UV}$ light yield the $\mathrm{Au}(\mathrm{I})$ congeners in a clean photo-reaction.

\section{Introduction}

Numerous publications dealing with the synthesis, solid state structures and applications of silver(I), gold(I), and gold(III) complexes bearing $\mathrm{N}$-heterocyclic carbenes (NHC) have been published in the last decade and have been summarised in several review articles. ${ }^{1}$ In particular, the interest in $\mathrm{NHC}-\mathrm{Ag}(\mathrm{I})$ complexes has grown significantly since Wang and Lin proved their capability as versatile carbene transfer agents and a plethora of compounds have been reported. ${ }^{1-4}$ In the case of NHC$\mathrm{Au}$ complexes intensive research activities were stimulated by their pharmaceutical potential as anticancer, antiarthritic, and antibacterial agents as well as their catalytic activities for unique $\mathrm{C}-\mathrm{C}, \mathrm{C}-\mathrm{O}$, and $\mathrm{C}-\mathrm{N}$ bond-forming reactions. ${ }^{5-8}$ Nevertheless, the chemistry of gold is still dominated by the oxidation state +1 and the linearly coordinate complexes of the type $\mathrm{NHC}-\mathrm{Au}(\mathrm{I})-\mathrm{X}$ or $\left[(\mathrm{NHC})_{2} \mathrm{Au}\right] \mathrm{X}$, which are usually synthesized by the reaction of $\mathrm{R}_{2} \mathrm{SAuX}\left(\mathrm{R}_{2} \mathrm{~S}=\mathrm{Me}_{2} \mathrm{~S}\right.$, tht, $\mathrm{X}=$ halide $)$ with a NHC-Ag

Institut für Anorganische Chemie, Johannes Kepler Universität Linz, Altenbergerstr.69, A-4040,Linz, Austria.E-mail: uwe.monkowius@jku.at ${ }^{b}$ Institut für Chemische Technologie Organischer Stoffe, Johannes Kepler Universität Linz, Altenbergerstr. 69, 4040, Linz, Austria

'Zentrale Analytik der Universität Regensburg, Röntgenstrukturanalyse, Universitätsstr. 31, 93053, Regensburg, Germany

${ }^{d G e o z e n t r u m ~-~ U n i v e r s i t a ̈ t ~ W i e n, ~ I n s t i t u t ~ f u ̈ r ~ M i n e r a l o g i e ~ u n d ~ K r i s t a l l o g r a-~}$ phie, Althanstr. 9, 1090, Wien, Austria

${ }^{e}$ Materialwissenschaften und Physik, Abteilung Materialchemie, ParisLodron Universität Salzburg, Hellbrunner Str. 34, 5020, Salzburg, Austria $\dagger$ Electronic supplementary information (ESI) available: Figures, spectra, and tables giving additional analytical and computational details. CCDC reference numbers 830155-830166, 830315. For ESI and crystallographic data in CIF or other electronic format see DOI: $10.1039 / \mathrm{cldt} 11175 \mathrm{~b}$ complex or the free carbene. Reports about Au(III) complexes are less frequent. ${ }^{6,8-12}$ As the direct synthesis starting from an $\mathrm{Au}(\mathrm{III})$ precursor (e.g. $\mathrm{KAuCl}_{4}$ ) only works with special functionality on the $\mathrm{NHC}$ ligand, ${ }^{12}$ they are mostly synthesized by the oxidation of the corresponding $\mathrm{Au}(\mathrm{I})$ complexes with halogens $\left(\mathrm{Cl}_{2}, \mathrm{Br}_{2}\right.$, $\mathrm{I}_{2}$ ). The majority of $\mathrm{NHC}-\mathrm{Au}(\mathrm{III})$ complexes are of the type $(\mathrm{NHC}) \mathrm{AuX} \mathrm{X}_{3}$ or $\left[(\mathrm{NHC})_{2} \mathrm{AuX}_{2}\right] \mathrm{X}$. The exchange of the halides by other anionic (or neutral) ligands seems to be critical and leads frequently to the reduction to $\mathrm{Au}(\mathrm{I})$ or decomposition. Some of the rare examples are the recently published carbene bearing complexes of the type $(\mathrm{NHC}) \mathrm{Au}(\mathrm{R}) \mathrm{X}_{2}\left(\mathrm{R}=\mathrm{C}_{6} \mathrm{H}_{5}, \mathrm{C}_{6} \mathrm{~F}_{5}, \mathrm{Me} ; \mathrm{X}=\right.$ Cl, I) ${ }^{6,11}$

Light and temperature sensitivity is a general feature of coinage metal complexes. The decomposition of such complexes often leads to the metal, sometimes in colloidal form. For (organometallic) gold(III) complexes, the reductive elimination involving carbon-carbon or element-element bond formations is well documented. ${ }^{13}$ Albeit known for a very long time, studies about photochemical transformations of gold(I) and especially of gold(III) compounds are still scarce. ${ }^{14}$ The thoroughly investigated tetrachloroaurate anion $\left[\mathrm{AuCl}_{4}\right]^{-}$undergoes photoreduction in the presence of oxidizable substrates (e.g. alcohols) via $\left[\mathrm{AuCl}_{2}\right]^{-}$ to eventually form elemental gold. ${ }^{15}$ If reducible substances like alkyl halides or $\mathrm{O}_{2} / \mathrm{Cl}^{-}$are present, $\left[\mathrm{AuCl}_{2}\right]^{-}$can be photooxidized to $\mathrm{AuCl}_{4}{ }^{-} \cdot{ }^{16}$ Analogous photo-reactivity has been found for $\mathrm{LAuX}_{3}(\mathrm{~L}=$ phosphane, $\mathrm{X}=\mathrm{Br}, \mathrm{Cl}) .{ }^{17}$ For clean photoreductive elimination of $\mathrm{X}_{2}$ from a $\mathrm{LAuX}_{3}$ complex according to eqn (1), a halogen trap (alkene, alcohol) is required in solution, whereas in the solid state due to the volatility of $X_{2}$ no trap is needed. Remarkably, no reduction to elemental gold took place under these conditions. 


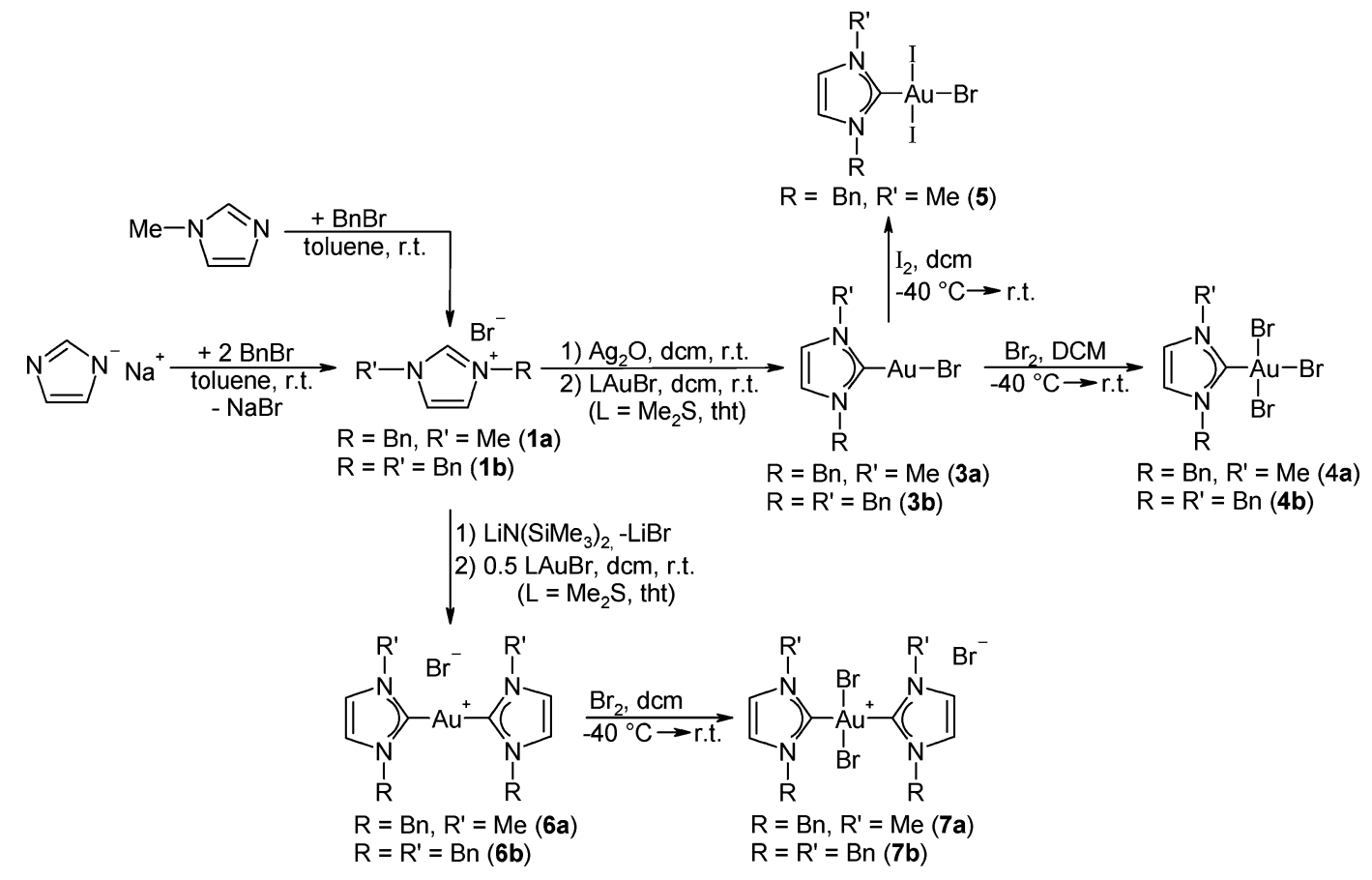

Scheme 1

$$
\mathrm{LAuX}_{3} \stackrel{-\mathrm{x}_{2}}{\longrightarrow} \mathrm{LAuX}
$$

The photoreaction proceeds from a ligand-to-metal charge transfer (LMCT) state. In the case of late transition metal halides, a LMCT excitation often causes formal one-electron reduction of the metal and release of a $\mathrm{X}^{\cdot}$ radical, ${ }^{18}$ which means for $\mathrm{Au}(\mathrm{III})$ complexes formal reduction of the gold atom to the relatively unstable $\mathrm{Au}(\mathrm{II})$ in the initial step. In subsequent thermal reactions either reduction to $\mathrm{Au}(\mathrm{I})$ and liberation of another $\mathrm{X}^{*}$ or disproportion [2 $\mathrm{Au}(\mathrm{II}) \rightarrow \mathrm{Au}(\mathrm{I})+\mathrm{Au}(\mathrm{III})]$ takes place.

In this contribution we present the synthesis and structural characterization of gold(III) complexes of the type (NHC)AuBr${ }_{3}$ and [(NHC $\left.)_{2} \mathrm{AuBr}_{2}\right] \mathrm{Br}$ [(NHC = 1-Methyl-3-benzylimidazol-2-ylidene (= MeBnIm), and 1,3-dibenzylimidazol-2-ylidene $\left.\left(=\mathrm{Bn}_{2} \mathrm{Im}\right)\right]$ and their reactivity towards anionic ligands. In addition, their photochemical reactivity is studied.

\section{Results and discussion}

\section{Synthesis}

The imidazolium bromides [MeBnImH] Br (1a) and $\left[\mathrm{Bn}_{2} \operatorname{ImH}\right] \mathrm{Br}$ (1b) are readily prepared by the reactions of benzylbromide with methylimidazole or sodium imidazolide in toluene, respectively. Reactions with an excess of $\mathrm{Ag}_{2} \mathrm{O}$ in DCM yield the Ag-carbenes $\mathbf{2} \mathbf{a} / \mathbf{b}$ in good yields and high purity as white powders. The stoichiometric reactions with $\mathrm{LAuBr}\left(\mathrm{L}=\mathrm{tht}, \mathrm{Me}_{2} \mathrm{~S}\right)$ in DCM give the colourless $\mathrm{Au}(\mathrm{I})$ complexes $\mathbf{3} \mathbf{a} / \mathbf{b}$, which can be oxidized by $\mathrm{Br}_{2}$ at $-40{ }^{\circ} \mathrm{C}$ to the corresponding yellow (NHC) $\mathrm{AuBr}_{3}$ $\mathbf{4 a} / \mathbf{b}$ complexes. Oxidation with iodide under similar conditions yields the mixed ligand complex (NHC) $\mathrm{AuI}_{2} \mathrm{Br}$ (5) as brown powder. The homoleptic, ionic compounds $\left[(\mathrm{NHC})_{2} \mathrm{Au}\right] \mathrm{Br} \mathbf{6 a} / \mathbf{b}$ are synthesized by the reaction of $\mathrm{LAuBr}\left(\mathrm{L}=\right.$ tht, $\left.\mathrm{Me}_{2} \mathrm{~S}\right)$ and the free carbenes, which are in situ prepared by the reaction of the imidazolium bromides and $\mathrm{LiN}\left(\mathrm{SiMe}_{3}\right)_{2}$ in $\mathrm{DCM}$ at $\mathrm{rt}$ under inert conditions. The oxidation of $6 \mathbf{a} / \mathbf{b}$ yields the $\mathrm{Au}(\mathrm{III})$ complexes $\left[(\mathrm{NHC})_{2} \mathrm{AuBr}_{2}\right] \mathrm{Br} \mathbf{7 a} / \mathbf{b}$ as yellow powders. All compounds are perfectly stable in solution and solid state at ambient conditions.

\section{Characterization}

All compounds yield the expected ${ }^{1} \mathrm{H}$ NMR spectra. Upon complex formation the signals for the $\mathrm{C} 2-\mathrm{H}$ imidazolium protons vanish (see Experimental section). In the ${ }^{13} \mathrm{C}$ NMR spectra, the $\mathrm{C} 2$ carbon atom is most affected by the ligation to the metal and by the change of the oxidation state and coordination environment (Table 1). With respect to the imidazolium salt, the $\mathrm{C} 2$ nucleus of the Ag compounds $\mathbf{2 a} / \mathbf{b}$ resonates considerable downfield by around $44 \mathrm{ppm}$ at $\sim 181 \mathrm{ppm}$. There are considerable differences between the neutral and ionic gold complexes: the carbene carbon atom of both the neutral $\mathrm{Au}(\mathrm{I})$ and the $\mathrm{Au}(\mathrm{III})$ complex (3a/b and $\mathbf{4 a} / \mathbf{b})$ each have signals at higher field than the corresponding ionic counterpart $(6 \mathbf{a} / \mathbf{b}$ and $7 \mathbf{a} / \mathbf{b})$ reflecting the higher positive charge density on the gold atom. The highest downfield shifts for the $\mathrm{C} 2$ are found for the ionic $\mathrm{Au}(\mathrm{I})$ complex, whereas the neutral $\mathrm{Au}(\mathrm{III})$ have signals in the region of the imidazolium salt. For comparison, typical ${ }^{13} \mathrm{C}$ chemical shifts of gold complexes bearing the

Table $1{ }^{13} \mathrm{C}-\mathrm{NMR}$ chemical shift for the $\mathrm{C} 2$ carbon atom in compounds 1-7 in $\mathrm{d}_{6}$-DMSO

\begin{tabular}{lll}
\hline & $\mathrm{R}=\mathrm{Me}, \mathrm{R}^{\prime}=\mathrm{Bn}$ & $\mathrm{R}=\mathrm{R}^{\prime}=\mathrm{Bn}$ \\
\hline Imidazolium bromide & 137.0 & 136.7 \\
$\mathrm{Ag}$ & 180.7 & $181.9^{20}$ \\
Neutral Au(I) & 172.7 & 169.1 \\
Ionic Au(I) & 186.4 & 182.9 \\
Neutral Au(III) & 134.6 & 136.3 \\
Ionic Au(III) & $149.7 / 149.8$ & 150.1 \\
\hline
\end{tabular}


non-substituted, unsaturated imidazol-2-ylidene moiety are depicted in Fig. 1. An analogue illustration for NHC-Ag complexes would be less meaningful due to extensive ligand scrambling equilibria in solution, which means that the molecular constitution of the NHC-Ag complexes in the solid state might not be retained in solution and a well-founded description of the silver coordination environment would be difficult. ${ }^{9}$ For gold this dynamic behaviour is less pronounced and it can be assumed that the constitution is identical both in the solid state and in solution. It was previously pointed out that the carbene carbon resonance is upfield shifted with increasing Lewis acidity of the metal. ${ }^{9 e, 19}$ The higher electronegativity of the chloride ligand leads to higher Lewis acidity of the gold(I) atom compared to the bromide congeners. Accordingly, the $\mathrm{C} 2$ of the gold chlorides resonates upfield compared to the gold bromides. In complexes of the type $\left[(\mathrm{NHC})_{2} \mathrm{Au}\right]^{+}$the coordination of an additional $\mathrm{NHC}$ ligand enhances the electron density on the gold atom, thus lowering its Lewis acidity: the C2 signal is considerably shifted downfield. Upon oxidation to $\mathrm{Au}(\mathrm{III})$, the acidity is further increased resulting in a significant upfield shift of the $\mathrm{C} 2$ resonances. Interestingly, the $\mathrm{C} 2$ resonances of the neutral $\mathrm{Au}(\mathrm{III})$ complexes are very similar to the imidazolium salt. Albeit the proton and $\mathrm{a}-\mathrm{AuBr}_{3}$ group are not isolobal, it is tempting to speculate that the $\mathrm{Au}(\mathrm{III})$ atom has at least a comparable electronic effect on the $\mathrm{C} 2$ atom like a proton.



Fig. $1{ }^{13} \mathrm{C}$ NMR shifts of the carbene carbon atom $\mathrm{C} 2$ of different gold complexes bearing the (non-substituted) imidazol-2-ylidene moiety. NMR data were taken from ref. $1 b, 6,9 f$ and $10 b]$.

The unsymmetrical substituted NHC Au(III) complex 7a shows two sets of signals in its ${ }^{1} \mathrm{H}$ - and ${ }^{13} \mathrm{C}$-NMR spectra indicative of syn-/anti-isomerism of this compound (Fig. 2 and Fig. S1). $\dagger$ The ratio of the integrals of each signal set varies slightly from batch to batch but is close to $1: 1$ for both isomers. The shifts of all $\mathrm{H}$ - and

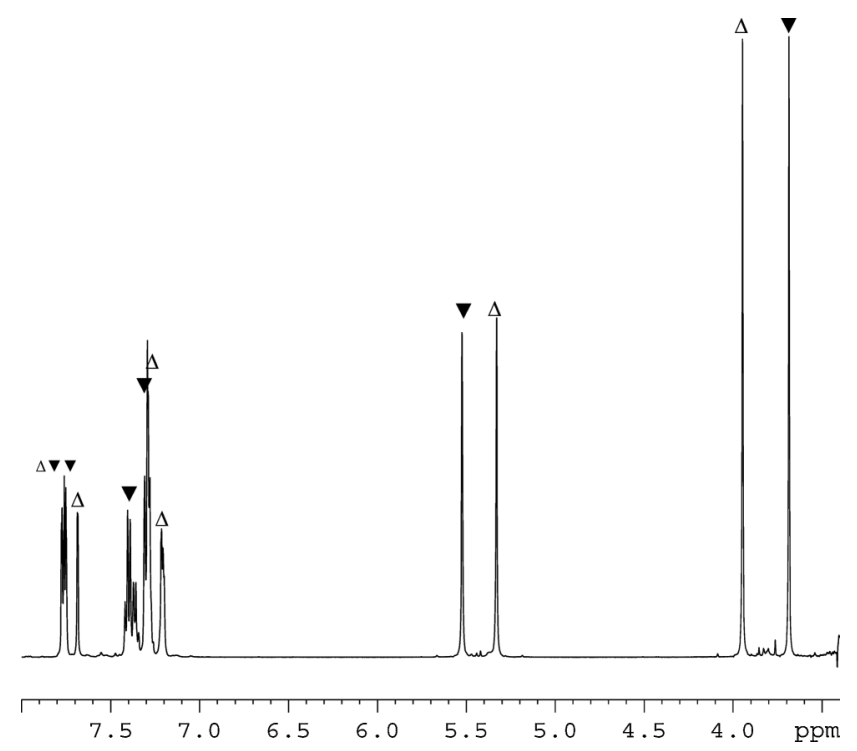

Fig. $2{ }^{1} \mathrm{H}$ NMR spectrum of $7 \mathbf{a}$ in DMSO-d 6 ( $\mathbf{\nabla}$ - anti, $\triangle-$ syn isomer).
C-atoms have unambiguously been assigned by ${ }^{1} \mathrm{H}-{ }^{1} \mathrm{H}-\mathrm{NOESY}$ and ${ }^{1} \mathrm{H}-{ }^{13} \mathrm{C}$ HSQC spectra (Fig. S2 and S3). $\dagger$ In DMSO-d $\mathrm{d}_{6}$, the separation of the signals of the methyl protons is $52 \mathrm{~Hz}$ and of the methylene groups $40 \mathrm{~Hz}$ (at $200 \mathrm{MHz}$ ). Upon heating to $90{ }^{\circ} \mathrm{C}$, the peaks of the methyl and methylene groups are only slightly approaching each other ( $46 \mathrm{~Hz}$ for $\mathrm{CH}_{3}$ and $39 \mathrm{~Hz}$ for $\mathrm{CH}_{2}$ ), but virtually no change of the integrals and signal shape could be determined in the ${ }^{1} \mathrm{H}-\mathrm{NMR}$ spectra proving the high rotational barrier about the $\mathrm{C}-\mathrm{Au}$ axis. In $\mathrm{C}_{2} \mathrm{D}_{2} \mathrm{Cl}_{4}$ the chemical shifts are more affected by increasing temperature. At $100{ }^{\circ} \mathrm{C}$ the signals are broadened and the splitting is reduced from 75 to $60 \mathrm{~Hz}\left(\mathrm{CH}_{2}\right)$ and from 80 to $64 \mathrm{~Hz}(\mathrm{Me})$. Unfortunately, the coalescence temperature could not be reached because the compound starts to thermally reduce to the $\mathrm{Au}(\mathrm{I})$ complex above this temperature (vide infra).

For an estimation of the rotational barrier, quantum-chemical calculations were performed. Unlike the crystal structure, the optimized structure does not exhibit coplanar orientation of the imidazole ring planes but a somewhat twisted arrangement which reduces the sterical repulsion of the substituent (Fig. S4). $\dagger$ All calculated interatomic distances are in excellent agreement with the measured parameters from the solid state. In the following calculations one carbene ligand was kept fixed while the other was rotated about the $\mathrm{C} 2-\mathrm{Au}$ axis giving a rotational barrier of $\sim 60 \mathrm{~kJ} \mathrm{~mol}^{-1}$ (Fig. 3). Remarkably, this value is in good agreement with the determined rotational barriers of similar $\mathrm{Pd}$ and $\mathrm{Pt}$ compounds, ${ }^{21}$ but is inconsistent with the variable temperature NMR experiments from this work. For a barrier of $\sim 60 \mathrm{~kJ} \mathrm{~mol}^{-1}$ the coalescence temperature is estimated to be around $60^{\circ} \mathrm{C}$ applying the standard approximation for the relation between the activation enthalpy $\Delta G^{\#}$ and the coalescence temperature. ${ }^{22}$ In an attempt to clarify this discrepancy also solvent effects were included into the calculation using the COSMO model, ${ }^{23}$ however the calculated energy difference between the approximate rotational saddle point and the minimum conformation only slightly increased by $\sim 4 \mathrm{~kJ}$ $\mathrm{mol}^{-1}$. Currently we are not able to give a satisfying explanation of these findings.

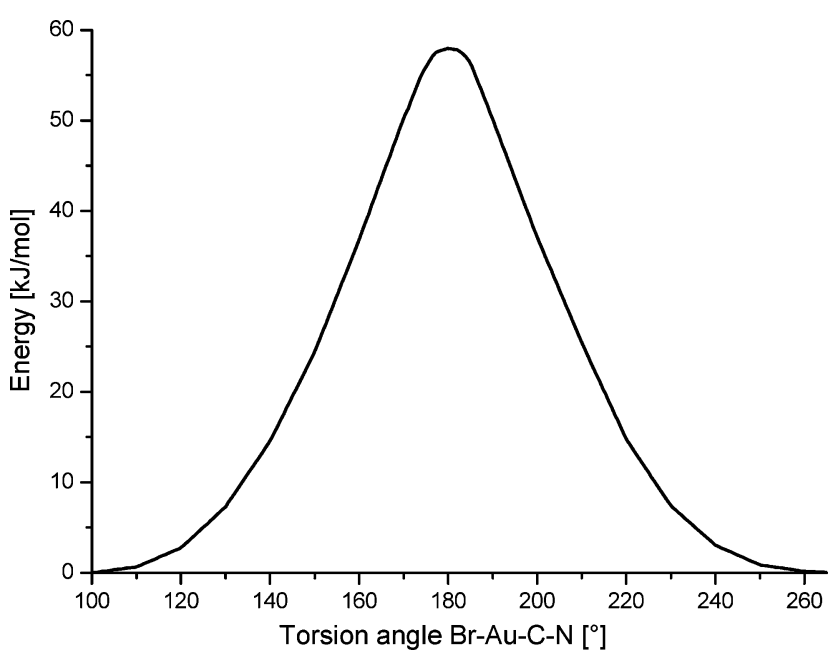

Fig. 3 DFT calculations on the PBE0/TZVPP level of theory.

\section{Crystal structures}

Complex 2a crystallizes in the triclinic space group $P \overline{1}(Z=2)$ in an ionic form with $\left[(\mathrm{NHC})_{2} \mathrm{Ag}\right]^{+}$cations and $\left[\mathrm{AgBr}_{2}\right]^{-}$anions 


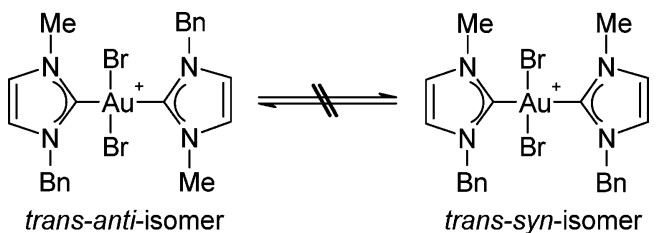

Scheme 2

aggregated to infinite [+ - ]-chains by short metal-metal contacts of 3.223(1) A (Fig. 4). The asymmetric unit contains one half of a formula unit with a $C_{2}$-axis passing through both $\mathrm{Ag}$ atoms resulting in a perfect linear coordination environment for the silver atoms in the ions $\left[(\mathrm{NHC})_{2} \mathrm{Ag}\right]^{+}$and $\left[\mathrm{AgBr}_{2}\right]^{-}$with an almost perpendicular orientation to each other $(\mathrm{C} 1-\mathrm{Ag} 1-\mathrm{Ag}-\mathrm{Br} 1$ $\left.92.7^{\circ}\right)$. Both imidazole ring planes are coplanar - a frequently found structural feature for the cation $\left[(\mathrm{NHC})_{2} \mathrm{M}\right]^{+}(\mathrm{M}=\mathrm{Au}$, $\mathrm{Ag}$ ). Despite the steric repulsion of the substituents in 1- and 3-position and the small energetic differences between a coplanar and perpendicular orientation of the imidazolyl rings, the coplanar arrangement is found more often, because $\pi$-backbonding contributions are more pronounced in a coplanar than in a perpendicular orientation. $^{24}$

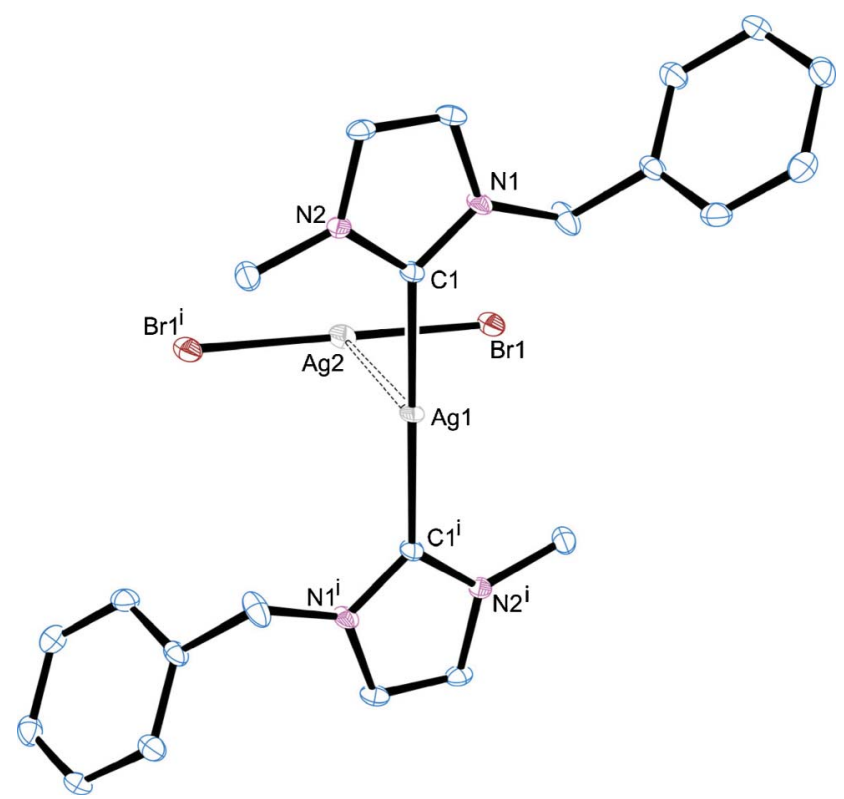

Fig. 4 Molecular structure of the silver complex 2a (ORTEP; displacement ellipsoids at the $50 \%$ probability level, $\mathrm{H}$ atoms are omitted for clarity). Selected bond lengths (Å) and angles (deg): Ag1-C1 2.092(2), Ag2-Br1 2.452(1), Ag1-Ag2 3.223(1), C1-Ag1-C1 ${ }^{\mathrm{i}} 180^{\circ}, \mathrm{Br} 1-\mathrm{Ag} 2-\mathrm{Br} 1^{\mathrm{i}}$ $180^{\circ}$.

As we point out in a recent publication, ${ }^{25}$ there are subtle effects defining the aggregation of NHC-Ag-complexes in the solid state: the competition between the neutral form ( $\mathrm{NHC}) \mathrm{AgCl}$ and the ionic form $\left[(\mathrm{NHC})_{2} \mathrm{Ag}\right]\left[\mathrm{AgCl}_{2}\right]$ is caused by ligand scrambling reactions and the ionic form is favoured by using polar solvents during the crystallization process. In general, the majority of halogenoargentates are oligo- or polymer anions. Isolated $\left[\mathrm{AgX}_{2}\right]^{-}$ units $\left(\mathrm{X}=\right.$ halogenide) are rarely found in the solid state. ${ }^{26}$ Interestingly, a CSD query revealed that the majority of crystal structures containing an isolated $\left[\mathrm{AgX}_{2}\right]^{-}$anion are complexes of the type $\left[(\mathrm{NHC})_{2} \mathrm{Ag}\right]\left[\mathrm{AgX}_{2}\right]$ and among theses structures, only one does not exhibit short Ag $\cdots$ Ag distances, presumably because of steric reasons. ${ }^{27}$ Another frequently found structural motive is that of the dimeric $\left[\mathrm{Ag}_{2} \mathrm{X}_{4}\right]^{2-}$ anion bridging two adjacent $\left[(\mathrm{NHC})_{2} \mathrm{Ag}\right]^{+}$ cations by short $\mathrm{Ag} \cdots \mathrm{Ag}$ contacts. ${ }^{28}$ Therefore, it is tempting to speculate that the ionic aggregation pattern is governed synergetically by both attractive closed shell $\mathrm{d}^{10}-\mathrm{d}^{10}$ as well as Coulombic and higher mulipolar interactions (e.g. quadropole-quadropole interactions which can in cases even outperform metallophilic interaction $\mathrm{s}^{29}$ ). Nevertheless, the energetic differences between the different aggregation types seem to be small and the aggregation is very sensitive to small changes in crystallization conditions and alterations of the substitution of the NHC-ligand.

In complexes $\mathbf{3 a}$ and $\mathbf{3 b}($ Fig. $5+6$ ) the $\mathrm{Au}(\mathrm{I})$ atoms are almost linearly coordinated by the carbene carbon and the bromide atoms $\left.\left[\mathrm{C} 1-\mathrm{Au} 1-\mathrm{Br} 1 \mathbf{1 7 6 . 5}^{\circ}\right)^{\circ}(\mathbf{3 a}) ; 178.1(2)^{\circ}(\mathbf{3 b})\right]$. Examples of a ligand distribution forming the ionic species $\left.\left[\mathrm{L}_{2} \mathrm{Au}\right]^{+}[\mathrm{AuX}]_{2}\right]^{-}$analogous to $\mathbf{2 a}$ are very limited for gold(I) complexes. ${ }^{30}$ All interatomic distances lie in the expected range: whereas the Au1-Br1 distances

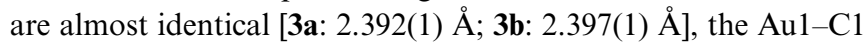
distance in 3a [1.979(8) $\AA$ ] is slightly shorter than in 3b [2.022(8) $\AA$ ] . The molecules exist as monomeric units not associated via aurophilic interactions.

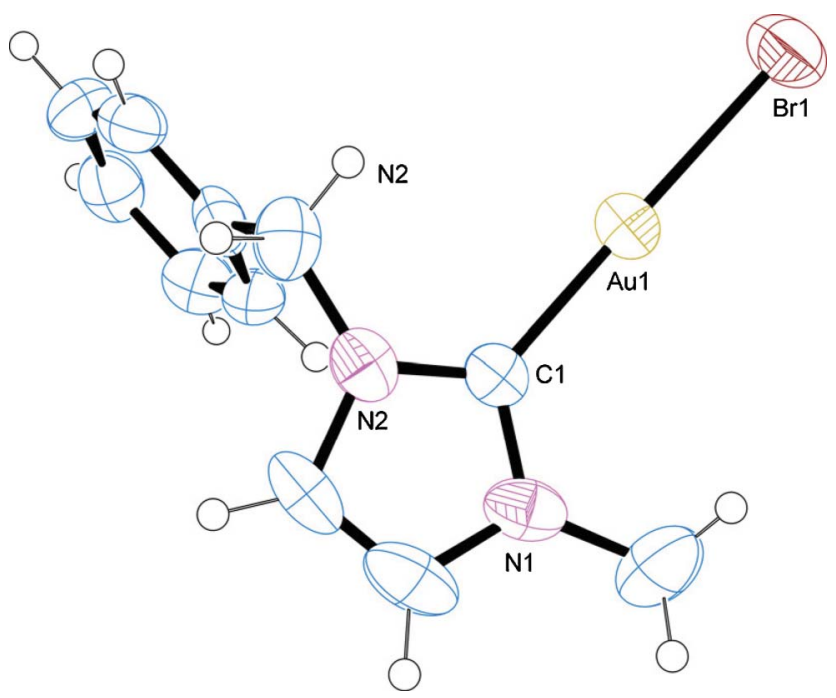

Fig. 5 Molecular structure of 3a. Selected bond lengths $(\AA)$ and angles (deg): Au1-C1 1.979(8), Au1-Br1 2.392(1), C1-Au1-Br1 176.5(2).

The $\mathrm{Au}(\mathrm{III})$ atoms in $\mathbf{4 b}$ and $\mathbf{5}$ exist in a distorted square-planar environment defined by the carbene-C, and three halogene atoms (Fig. $7+8$ ). In complex 5 the bromide ligand is strictly in the trans position. The angles between the imidazolyl ring plane and the gold coordination plane are $\sim 80^{\circ}$. It should be noted that $\mathrm{Au}$ (III) complexes bearing different halide ligands are rare and so far only the crystal structure of the complex $\mathrm{Ph}_{3} \mathrm{PAuBr}_{2} \mathrm{Cl}$ has been published. ${ }^{31}$

Complex 6a crystallizes in the trigonal space group $R \overline{3} c$ $(Z=18)$ as a highly symmetrical trinuclear, bromide centred aggregate of the formula $\left\{\left[(\mathrm{NHC})_{2} \mathrm{Au}\right]_{3}\left(\mu_{3}-\mathrm{Br}\right)\right\} \mathrm{Br}_{2}$ (Fig. 9). The three $\left[(\mathrm{NHC})_{2} \mathrm{Au}\right]^{+}$cations are disposed about a threefold axis linked by one bromine atom with an Au1-Br1 distance of 3.2647(3) $\AA$, which is well below the sum of their van-der-Waals radii 


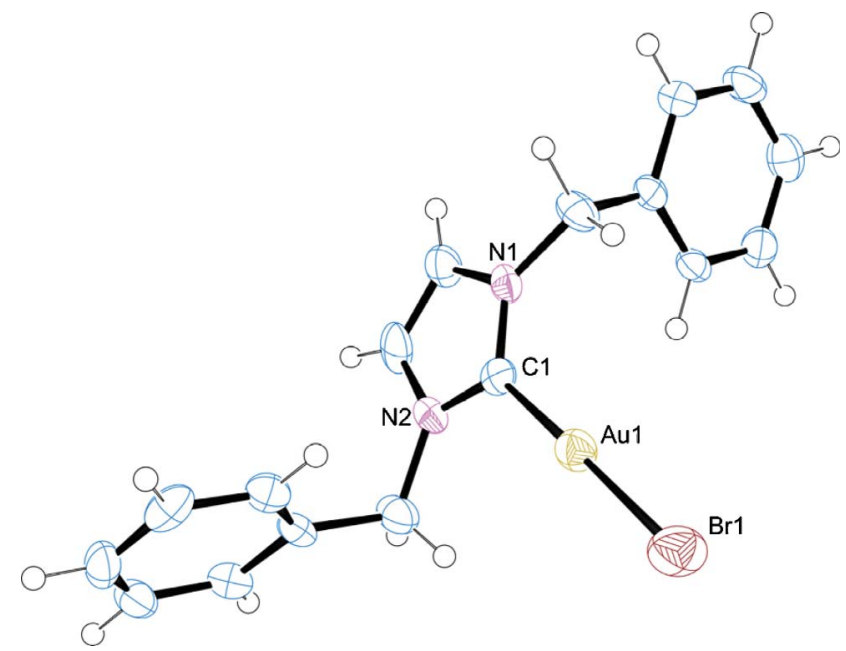

Fig. 6 Molecular structure of $\mathbf{3 b}$. Selected bond lengths $(\AA)$ and angles (deg): Au1-C1 2.022(8), Au1-Br1 2.397(1), C1-Au1-Br1 178.1(2).

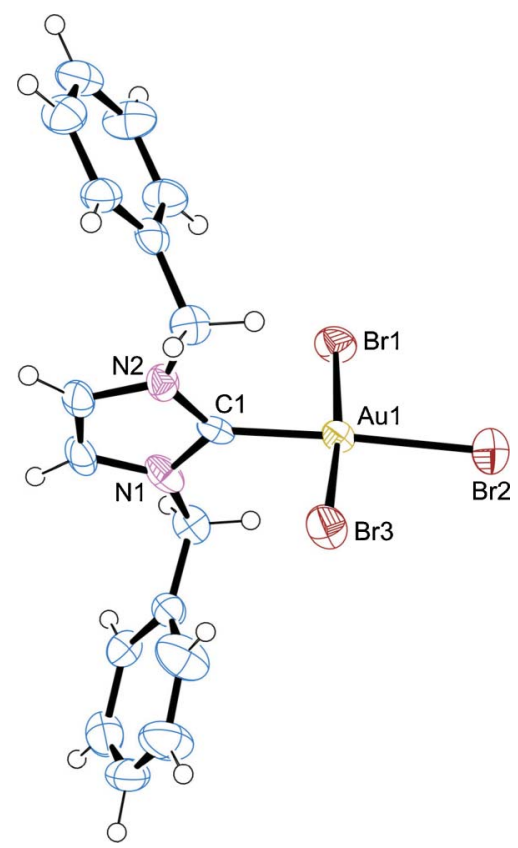

Fig. 7 Molecular structure of $\mathbf{4 b}$. Selected bond lengths $(\AA)$ and angles (deg): Au1-C1 2.031(8), Au1-Br1 2.420(1), Au1-Br2 2.442(1), Au1-Br3 2.429(1), C1-Au1-Br1 87.3(2), C1-Au1-Br2 177.1(2), C1-Au1-Br3 87.3(2), Br1-Au1-C1-N1 80.6(6).

$(3.51 \AA$ ) but substantially longer than those of non-bridging, terminal bromide ligands $(\sim 2.4 \AA)$. This arrangement results in the very rare T-shape coordination of the gold atom which is known for only a few phosphane complexes of the type $\left(\mathrm{R}_{3} \mathrm{P}\right)_{2} \mathrm{AuX}$ $\left(\mathrm{X}=\mathrm{Cl}, \mathrm{Br}, \mathrm{I}, \mathrm{BF}_{4}\right){ }^{32}$ The net $2+$ charge is balanced by two noninteracting bromide ions. The distance between two gold atoms in the trimer is $5.655 \AA$ and out of the standard range for $\mathrm{Au} \cdots \mathrm{Au}$ bonds $\left(<3.5 \AA^{33}\right)$. Within the cation both imidazole ring planes are approaching a perpendicular orientation $\left[\mathrm{N} 1-\mathrm{C} 1-\mathrm{Cl}^{\mathrm{i}}-\mathrm{N} 1^{\mathrm{i}}\right.$ 99.7(4)], presumably because of steric reasons. To the best of our knowledge, this aggregation pattern is unprecedented for gold, but the isostructural silver complex $\left\{\left[(\mathrm{NHC})_{2} \mathrm{Ag}\right]_{3}\left(\mu_{3}-\mathrm{I}\right) \mathrm{I}_{2}(\mathrm{NHC}=3-\right.$ methyl-1-picolyl-imidazol-2-ylidene) was reported previously. ${ }^{34}$

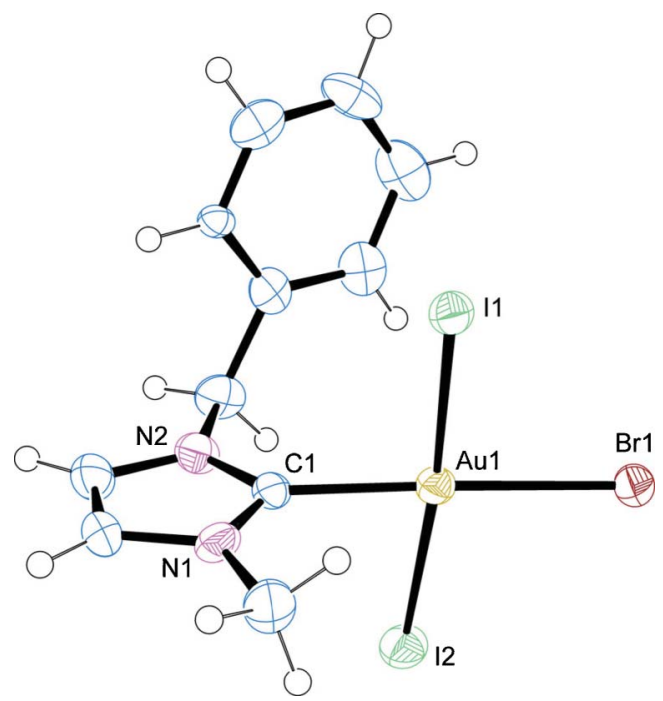

Fig. 8 Molecular structure of 5. Selected bond lengths $(\AA)$ and angles (deg): Au1-C1 2.012(8), Au1-Br1 2.475(1), Au1-I1 2.614(1), Au1-I2 2.608(1), C1-Au1-Br1 178.4(2), C1-Au1-I1 88.7(2), C1-Au1-I2 81.1(2), I1-Au1-C1-N1 82.9(7).

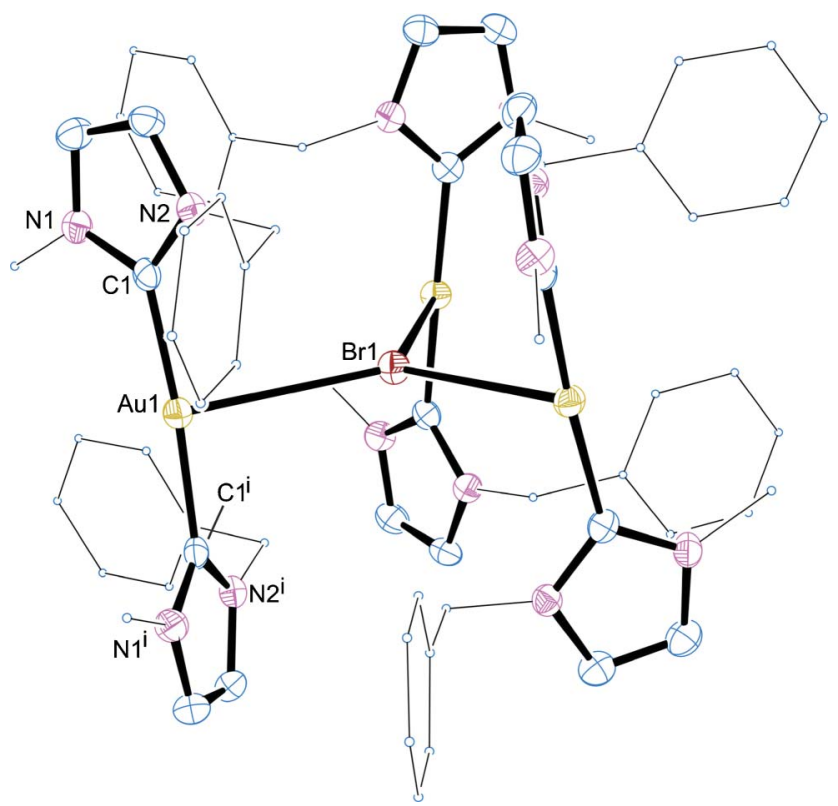

Fig. $9\left[\mathrm{Au}_{3} \mathrm{Br}\right]^{2+}$ cation in the crystals of $\mathbf{6 a}$ (displacement ellipsoids at the $30 \%$ probability level, $\mathrm{H}$-atoms are omitted and the carbon atoms of the methyl- and benzyl-substituent are drawn as small spheres for the sake of clarity). Selected bond lengths ( $)$ and angles (deg): Aul-C1 2.035(4), $\mathrm{C} 1-\mathrm{Au} 1-\mathrm{Cl}^{\mathrm{i}}$ 175.0(2), Au1-Br1 3.2647(3), N1-C1-C1 ${ }^{\mathrm{i}}-\mathrm{N} 1^{\mathrm{i}}$ 99.7(4).

The crystals of $\mathbf{6} \mathbf{b}$ are monoclinic $\left(P 2_{1} / c\right)$ and contain isolated $\left[(\mathrm{NHC})_{2} \mathrm{Au}\right]^{+}$cations and bromide anions (Fig. 10). The gold atom is almost perfectly linearly coordinated by the carbene carbon atom $\left[\mathrm{C} 1-\mathrm{Au} 1-\mathrm{C} 18 \mathrm{178.4}(4)^{\circ}\right]$, the imidazole ring planes are almost coplanar [N1-C1-C18-N4 8.4(9)] and the Au-C distances are comparable to the other $\mathrm{Au}-\mathrm{C}$ bond lengths presented here.

In the oxidized gold complexes $7 \mathbf{a}$ and $\mathbf{7 b}$ (Fig. 11 and 12), the gold atom exists in a square-planar coordination environment 


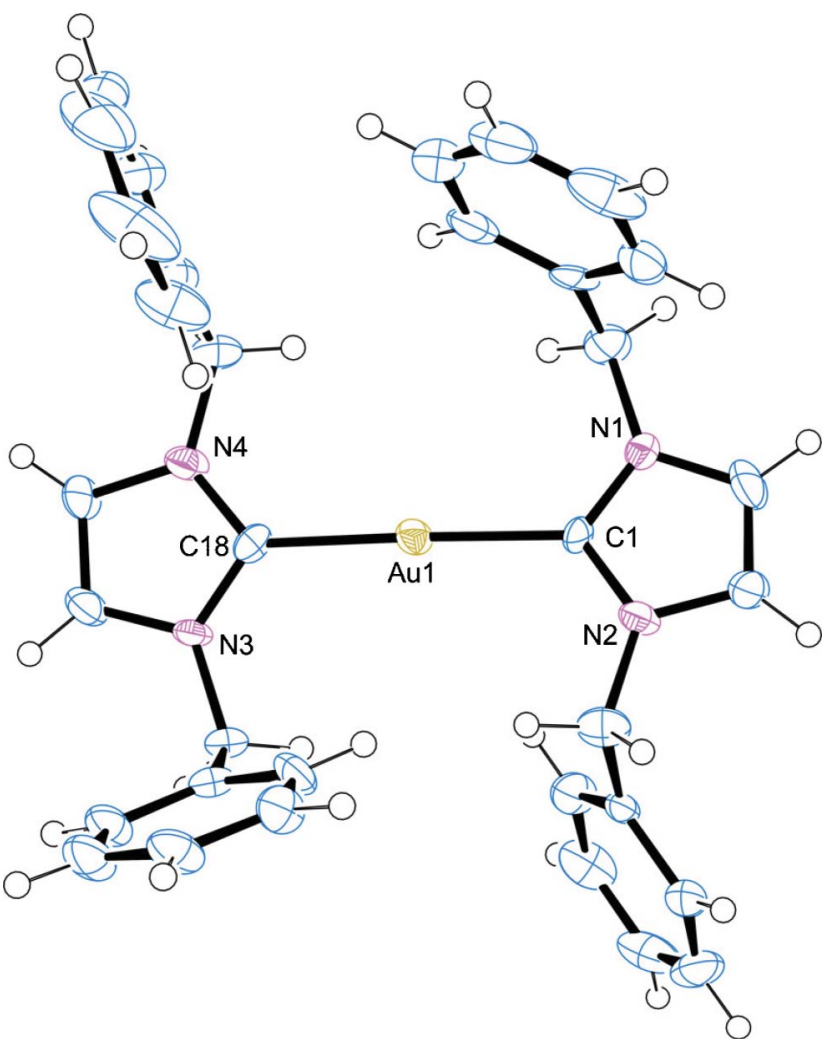

Fig. 10 Structure of the cation in crystals of $\mathbf{6 b}$. Selected bond lengths (A) and angles (deg): Au1-C1 2.06(1), Au1-C18 2.04(1), C1-Au1-C18 178.4(4), N1-C1-C18-N4 8.4(9).

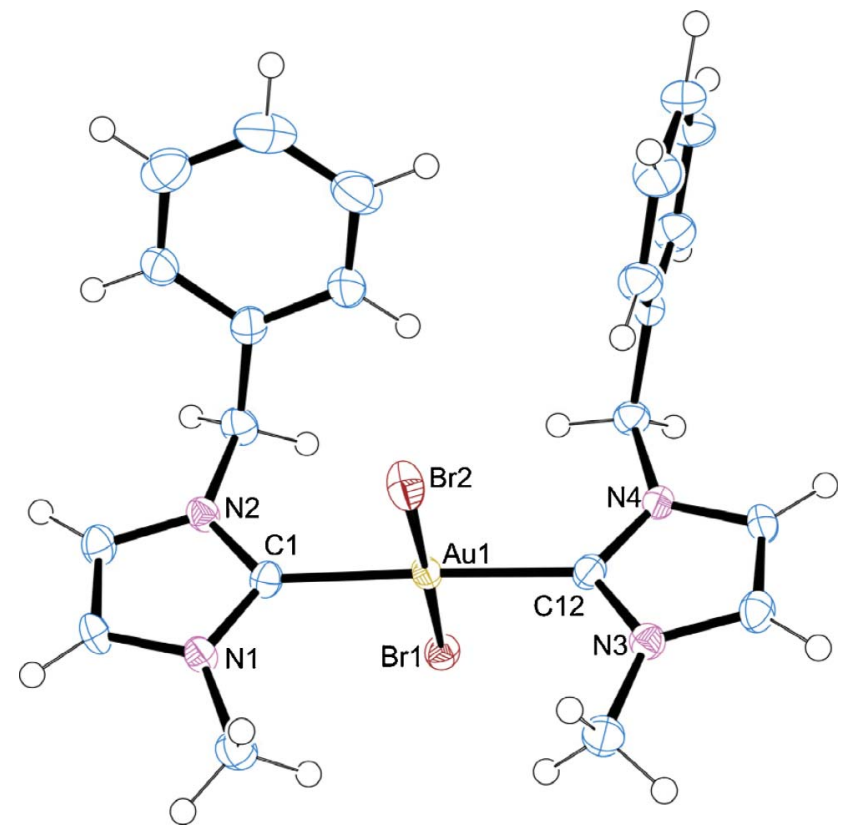

Fig. 11 Structure of the cation in crystals of 7a. Selected bond lengths (A) and angles (deg): Au1-C1 2.02(1), Au1-C12 2.04(1), Au1-Br1 2.416(1), Au1-Br2 2.433(1), C1-Au1-C12 176.7(2), C1-Au1-Br1 89.6(1), C1-Au1-Br2 89.5(1), N1-C1-Au1-Br1 100.9(4), N3-C12-Au1-Br1 104.4(4), N1-C1-C12-N3 3.6(6).

defined by two carbene carbon atoms and two bromide ligands. Interestingly, the $\mathrm{Au}-\mathrm{C}$ bond lengths in both complexes are nearly

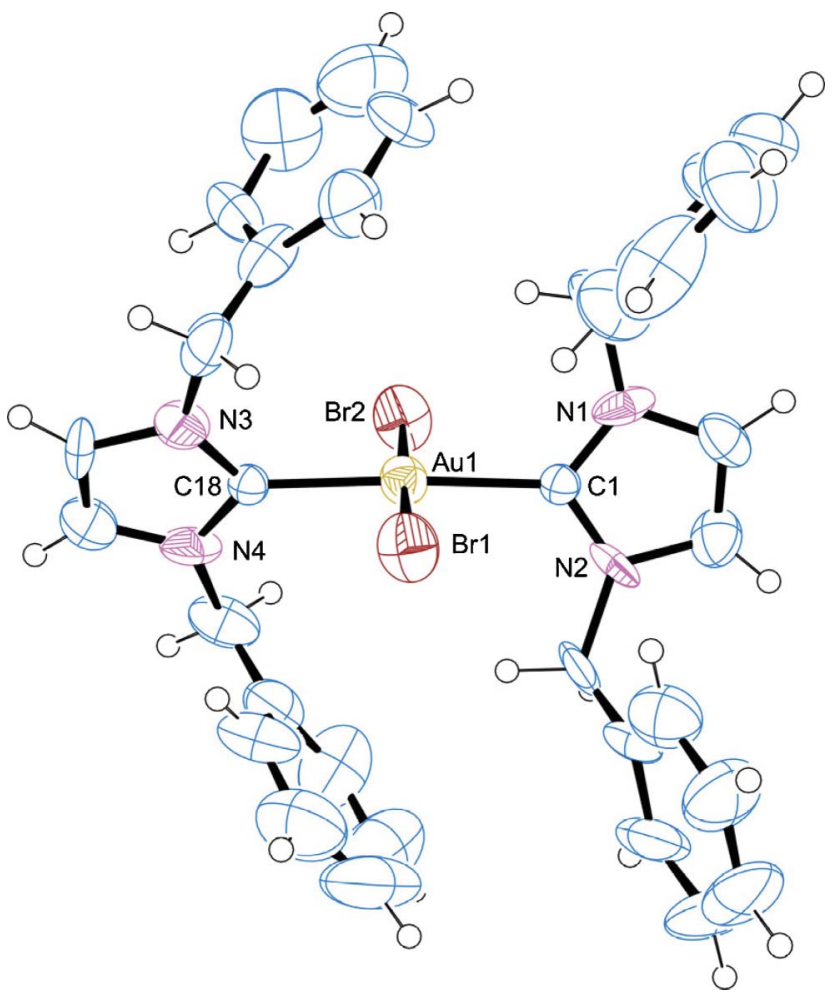

Fig. 12 Structure of the cation in crystals of $\mathbf{7 b}$. Selected bond lengths (A) and angles (deg): Au1-C1 2.05(2), Au1-C18 2.03(2), Au1-Br1 2.425(2), Au1-Br2 2.417(2), C1-Au1-C18 176.6(9), C1-Au1-Br1 90.5(6), C1-Au1-Br2 89.7(5), N1-C1-Au1-Br1 104(2), N3-C12-Au1-Br1 108(2), N1-C1-C18-N3 35.1(8).

not affected by the oxidation state of the gold atom. Again, the imidazole moiety is approaching coplanarity - presumably more because of the steric repulsion between the $\mathrm{Br}$ atoms and the carbene substituent than by $\pi$-backbonding effects which should be much weaker for $\mathrm{Au}(\mathrm{III})$ than for $\mathrm{Au}(\mathrm{I})$. Only the $s y n$-isomer of 7a could be characterized by single crystal X-ray diffraction.

\section{Reactivity study of the gold(III) complexes}

For the $\mathrm{Au}(\mathrm{III})$ complexes, the possibility to exchange bromide anions by other anionic ligands was investigated in a reactivity study. The scope of this screening was to find stable, isolatable compounds with different kinds of ligands capable of binding to $\mathrm{Au}(\mathrm{III})$ atoms. The main focus was laid on ligands with oxygen donor atoms as they might resist the oxidative environment of the $\mathrm{Au}(\mathrm{III})$ atom. Another motivation was to explore the still underdeveloped area of gold-oxygen chemistry. ${ }^{35}$ Beside the reported analysis, no excessive attempts were undertaken to identify possibly formed side products.

Both the neutral as well as the ionic complexes were treated with three (for $\mathbf{4 b}$ ) or two (for $7 \mathbf{c}=\left[(\mathrm{NHC})_{2} \mathrm{AuBr}_{2}\right] \mathrm{Cl}$ ) equivalents of $\mathrm{AgNO}_{3}, \mathrm{Ag}$ (acetate), $\mathrm{Ag}_{2}$ (oxalate), and $\mathrm{Ag}$ (benzoate), or a mixture of $\mathrm{AgBF}_{4} / \mathrm{Na}(\mathrm{OPh}), \mathrm{AgBF}_{4} / \mathrm{Na}\left(\mathrm{OC}_{6} \mathrm{Cl}_{5}\right)$, and $\mathrm{AgBF}_{4} / \mathrm{Na}(\mathrm{SPh})$. After filtration of the formed $\mathrm{AgBr}$ over celite the solvent was removed and the residue was re-crystallized from $\mathrm{DCM} / \mathrm{Et}_{2} \mathrm{O}$. In the case of $\mathbf{4 b}$, the reactions led to partial or complete decomposition to elemental gold and only intractable oily substances were formed. The ${ }^{1} \mathrm{H}-\mathrm{NMR}$ spectra of the residues 
revealed that basically the imidazolium salt was present. Only for $\mathrm{AgNO}_{3}$ a few crystals were isolated. A single crystal X-ray analysis revealed that $\left[(\mathrm{NHC})_{2} \mathrm{Au}\right] \mathrm{NO}_{3}$ was generated by the reduction and ligand scrambling (Fig. S5). $\dagger$ Because of the easy oxidation of thiolates a complete reduction and the formation of (NHC)AuSPh were observed for the reaction with thiophenolate. A similar reduction was reported for the anion $\left[\mathrm{Au}(\mathrm{III})(\mathrm{SR})_{4}\right]^{-}$forming the gold(I) species $\left[\mathrm{Au}(\mathrm{I})(\mathrm{SR})_{2}\right]^{-}$and dithiol RS-SR. ${ }^{13 \mathrm{c}}$ Due to the low quality of the crystals, the quality of the structural data is also low and will not be discussed here, but the identity of the substance is unambiguous. The molecular structure plot and detailed structure data can be found in the ESI (Fig. S6). $\dagger$ For $\mathbf{7 b}$ the reactions yield a complete or partial reduction of the $\mathrm{Au}(\mathrm{III})$ compound. The main product is in all cases the cation $\left[(\mathrm{NHC})_{2} \mathrm{Au}\right]^{+}$which can be detected by ${ }^{1} \mathrm{H}-\mathrm{NMR}$. From these reactions a single crystal suitable for X-ray diffraction of the chloride and tetrafluoroborate salt of $\left[(\mathrm{NHC})_{2} \mathrm{Au}\right]^{+}$could be isolated (Fig. S7 and S8). $\dagger$

In further experiments it was attempted to oxidize the neutral $\mathrm{Au}(\mathrm{I})$ complex $3 \mathrm{~b}$ with benzoylperoxide or $\left[\mathrm{NBu}_{4}\right]_{2} \mathrm{~S}_{2} \mathrm{O}_{8}{ }^{2-}$ to the corresponding $\mathrm{Au}(\mathrm{III})$ complex. No reaction and no decomposition could be detected by ${ }^{1} \mathrm{H}-\mathrm{NMR}$ spectroscopy at $\mathrm{rt}$ or $80^{\circ} \mathrm{C}$ proving the high stability of the NHC-gold(I) complex.

\section{Electronic absorption spectra and photochemistry}

All gold(III) complexes feature a long wavelength absorption above $300 \mathrm{~nm}$ (Fig. 13, S9-S11†). To assign the electronic transitions the thoroughly investigated square-planar d $\mathrm{d}^{8}$-anion $\mathrm{AuX}_{4}{ }^{-}(\mathrm{X}=\mathrm{Cl}, \mathrm{Br})$ can be used for comparison: ${ }^{36}$ e.g., a solution of $\mathrm{K}\left[\mathrm{AuBr}_{4}\right]$ in $\mathrm{MeCN}$ features signals at 394 and a shoulder at $\sim 460 \mathrm{~nm}$, which can be assigned to $\mathrm{n}(\mathrm{Br}) \rightarrow 5 \mathrm{~d}_{\mathrm{x} 2-\mathrm{y} 2}(\mathrm{Au})$ and $\pi(\mathrm{Br}) \rightarrow 5 \mathrm{~d}_{\mathrm{x} 2-\mathrm{y} 2}(\mathrm{Au})$ ligand-to-metal-charge-transfer (LMCT) states, respectively. The high energy band at $258 \mathrm{~nm}$ originates from a $\sigma(\mathrm{Br}) \rightarrow 5 \mathrm{~d}_{x 2-y_{2}}(\mathrm{Au})$ LMCT state (Fig. S12). $\dagger$ In other words, in square-planar $\mathrm{Au}(\mathrm{III})-$ halide complexes the HOMO is not constituted by $5 \mathrm{~d}$-orbitals of the gold atom but by low lying orbitals of the halide ligands. These low lying ligand orbitals facilitate a LMCT from the halides to the $5 \mathrm{~d}_{x 2-y 2}$ orbital of the strongly oxidizing gold atom upon light absorption. Due to coordination of a $\sigma$-donating ligand in complexes of the type $\mathrm{LAu}(\mathrm{III}) \mathrm{X}_{3}$ (e.g. $\mathrm{L}=$ phosphine, NHC; $\mathrm{X}=\mathrm{Cl}, \mathrm{Br}$ ) the $5 \mathrm{~d}_{\mathrm{x} 2-\mathrm{y} 2}$ orbital is further destabilized leading to a hypsochromic shift of the LMCT. In the analogues phosphine complex $\mathrm{Ph}_{3} \mathrm{PAuBr}_{3}$ the LMCT absorption is found at $346 \mathrm{~nm}^{17 b}$ compared to $\sim 335 \mathrm{~nm}$ for the neutral complexes $\mathbf{4 a} / \mathbf{b}$ indicative of the higher $\sigma$-donating character of the carbene ligand. An additional hypsochromic shift to $\sim 315 \mathrm{~nm}$ is caused by the coordination of a second NHC ligand in the case of the ionic complexes $7 \mathbf{a} / \mathbf{b}$. The high energy bands are due to $\pi-\pi^{*}$ transitions of the imidazolyl or phenyl moiety and might cover further, short wavelength LMCT transitions (Table 2).

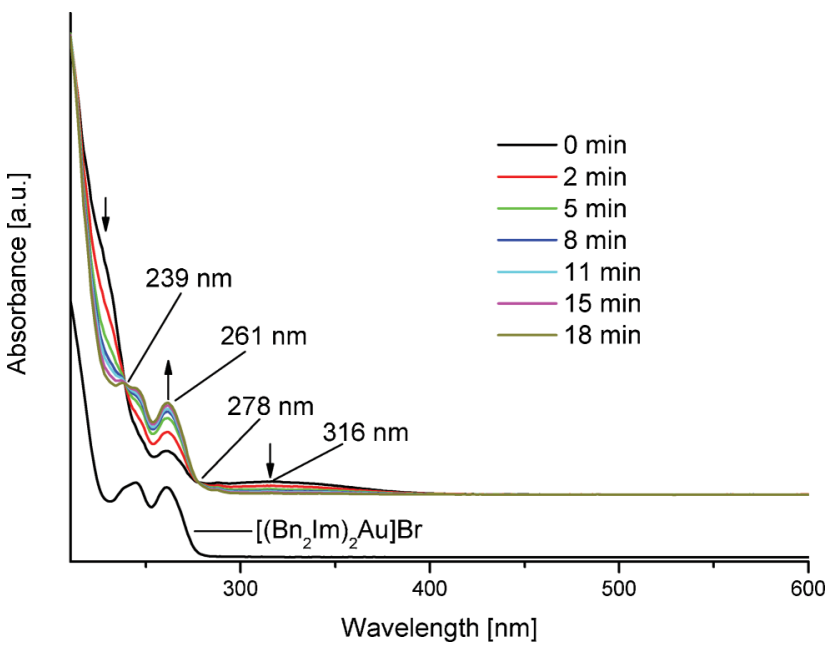

Fig. 13 Irradiation of $\left[\left(\mathrm{Bn}_{2} \mathrm{Im}\right)_{2} \mathrm{AuBr}_{2}\right] \mathrm{Br}$ in methanolic solution $(\mathrm{c}=1.2$ $10^{-5} \mathrm{~mol} \mathrm{~L}^{-1}$ ) with monochromatic light $\lambda=280 \mathrm{~nm}$. For comparison, the spectrum of $\left[\left(\mathrm{Bn}_{2} \mathrm{Im}\right)_{2} \mathrm{Au}\right] \mathrm{Br}$ (methanol, $\left.\mathrm{c}=1.010^{-5} \mathrm{~mol} \mathrm{~L}^{-1}\right)$ is also shown.

Upon irradiation with polychromatic light all gold(III) bromide complexes underwent photo-reduction to the respective gold(I) compounds. In no cases a decomposition and formation of elemental gold and also no plasmon resonance of colloidal gold at $\sim 520 \mathrm{~nm}^{37}$ are detectable. In Fig. 13 the time course of the absorbance changes while irradiating $(\lambda=280 \mathrm{~nm})$ a methanolic solution of complex $\mathbf{7 b}$ at room temperature is shown. The LMCT band at $316 \mathrm{~nm}$ is decreasing while the signal at $261 \mathrm{~nm}$ is increasing. The two isosbestic points at 239 and $278 \mathrm{~nm}$ are indicative of a clean photo-reaction. ${ }^{38}$ After 18 min the resulting spectrum shows the same spectral features as the gold(I) compound $\left[\left(\mathrm{Bn}_{2} \mathrm{Im}\right)_{2} \mathrm{Au}\right] \mathrm{Br}$. Both the ${ }^{1} \mathrm{H}-\mathrm{NMR}$ as well as the ESI-MS spectra prove the reduction to the gold(I) complex (Fig. S17 - S19). $\dagger$ There are no spectral variations of the non-irradiated solution even after several days under ambient conditions. All other $\mathrm{Au}(\mathrm{III})$ bromide complexes are reacting analogously (Fig. S13 - S16). The released bromine is further reacting with the solvent and therefore not visible in the UV-Vis spectra (Fig. S20†). ${ }^{39}$ Accordingly, the photo-reduction proceeds faster in methanol than in DMSO but there is no photo-reaction in water even upon elongated irradiation due to the decreasing ease of oxidation of these solvents. The oxidation of methanol and DMSO with bromine is astonishingly complex and leads to various reaction products, ${ }^{40}$ i.e. no oxidation products could be unambiguously identified by NMR or MS experiments. In similar experiments, ${ }^{41,42}$ ethanol or 2-propanol was used as reductant and indeed for the photo-reaction of $\mathbf{7 b}$ in a mixture of $\mathrm{EtOH} / \mathrm{d}_{6}$ DMSO $(1: 2)$ acetaldehyde and diethylacetal could be detected by ${ }^{1} \mathrm{H}-$ and ${ }^{13} \mathrm{C}-\mathrm{NMR}$.

Table 2 UV/Vis spectroscopic data of the gold complexes in methanolic solution

\begin{tabular}{lll}
\hline$\lambda_{\max }[\mathrm{nm}](\lg \varepsilon)$ & $\mathrm{R}=\mathrm{Me}, \mathrm{R}^{\prime}=\mathrm{Bn}$ & $\mathrm{R}=\mathrm{R}^{\prime}=\mathrm{Bn}$ \\
\hline Neutral Au(I) & $226(4.02), 233(4.05), 247(4.14)$ & $227(4.28), 235(4.41), 248(4.48)$ \\
Ionic $\mathrm{Au}(\mathrm{I})$ & $236(4.26), 243(4.28), 260(4.26)$ & $238(4.07), 245(4.57), 261(4.55)$ \\
Neutral Au(III) & $230(4.63), 334(3.59)$ & $231(4.93), 336(3.89)$ \\
Ionic $\mathrm{Au}(\mathrm{III})$ & $223(4.19), 315(3.68)$ & $230(\mathrm{sh}, 4.93), 247(\mathrm{sh}, 4.35), 261(4.23), 316(3.70)$ \\
\hline
\end{tabular}


The iodide complex $\mathbf{5}$ was not included in the photo-reactivity study because there are strong indications of a thermal equilibrium between $\mathrm{Au}(\mathrm{III})$ and $\mathrm{Au}(\mathrm{I})$ : (a) the ${ }^{1} \mathrm{H}-\mathrm{NMR}$ spectrum shows broad unresolved and/or more than one set of signals. The shifts of one signal set are very similar to the gold(I) complex 3a which was used as starting material (Fig. S21); $†$ (b) the UV-Vis spectrum in acetonitrile solution features bands at 290 and $361 \mathrm{~nm}$ which are characteristic for triiodide in acetonitrile (Fig. S22 $\dagger$ ). ${ }^{43}$ Because acetonitrile is capable of stabilizing a cationic species ${ }^{44}$ like $[(\mathrm{NHC}) \mathrm{Au}(\mathrm{I})(\mathrm{NCMe})]^{+}$we propose partial reduction of the gold(III) atom and dissociation of iodine and extensive ligand scrambling reactions, which eventually leads to the formation of a free triiodide anion. Due to its high extinction coefficient

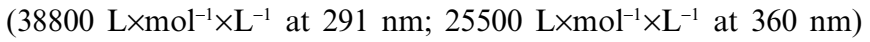
the triiodide anion dominates the spectrum even if the gold(III) complex or other (poly)halide species are still present. Similar equilibrium reactions are well documented for gold complexes $\mathrm{LAuI}_{3}$ bearing phosphane or isonitrile ligands ${ }^{45}$ as well as for the anion trans $-\left[(\mathrm{CN})_{2} \mathrm{AuI}_{2}\right]^{-}$which dissociate in solution into $\left[\mathrm{Au}(\mathrm{CN})_{2}\right]^{-}$und $\mathrm{I}_{2} \cdot{ }^{36 \mathrm{a}}$

\section{Conclusion}

Gold(III) complexes bearing NHC ligands of the type (NHC) $\mathrm{AuBr}_{3}$ and $\left[(\mathrm{NHC})_{2} \mathrm{AuBr}_{2}\right] \mathrm{Br}$ are readily accessible by oxidation of the $\mathrm{Au}(\mathrm{I})$ congener with $\mathrm{Br}_{2}$ as yellow solids. All attempts to exchange the bromide ligands by carboxylates, phenolates or thiolate result in the reduction of the $\mathrm{Au}$ (III) complex and isolation of a $\mathrm{Au}(\mathrm{I})$ species. Likewise, the oxidation of the $\mathrm{Au}(\mathrm{I})$ complexes with strong oxidants like benzoyl peroxide or $\mathrm{S}_{2} \mathrm{O}_{8}{ }^{2-}$ does not yield a $\mathrm{Au}(\mathrm{III})$ compound. The UV-Vis spectra of the NHC-gold(III) halides feature a broad low-energy LMCT band around $320 \mathrm{~nm}$. This LMCT exited state causes a reductive elimination of bromine and reduction of the $\mathrm{Au}(\mathrm{III})$ to $\mathrm{Au}(\mathrm{I})$ complex. Conversely, solvent molecules like methanol, ethanol or dimethyl sulfoxide function as trap of the formed bromine and are oxidized. Particularly remarkable is the high photochemical stability of the $\mathrm{Au}$ (I) complexes even under elongated illumination.

\section{Experimental}

\section{General}

All reactions and manipulations of air- and/or moisture sensitive compounds were carried out in an atmosphere of dry nitrogen using standard Schlenk techniques. Dichloromethane was dried and distilled over a $\mathrm{Na} / \mathrm{Pb}$ alloy. All solvents and other reagents were commercially obtained and used as received. NMR spectra were recorded either on a Bruker Digital Avance DPX 200 (200 MHz) or on an Avance DRX 500 (500 MHz) spectrometer and ${ }^{1} \mathrm{H}$ and ${ }^{13} \mathrm{C}$ shifts are reported in ppm relative to $\mathrm{SiMe}_{4}$ and were referenced internally with respect to the residual signal of the deuterated solvent. UV-Vis spectra were recorded on a Cary 300 Bio photometer. Single crystal structure analysis of the compounds $\mathbf{3 a}, \mathbf{3 b}, \mathbf{4 b}, \mathbf{6} \mathbf{a}, \mathbf{6 b}$ and $\mathbf{7 b}$ were carried out on a Bruker Smart X2S diffractometer whereas the structures of 5 and $7 \mathbf{a}$ were measured on a STOE-IPDS device ${ }^{46}$ with graphite-monochromated Mo-K $\alpha$ radiation $(\lambda=0.71073 \AA)$. For 2a, a Nonius Kappa diffractometer with a CCD area detector was used, employing the program suite COLLECT. ${ }^{47,48}$ Further crystallographic and refinement data can be found in Table 3 and 4. The structures were solved by direct methods (SIR-97 and SHELXS-97 $)^{49,50}$ and refined by full-matrix least-squares on $\mathrm{F}^{2}$ (SHELXL-97). ${ }^{51}$ The $\mathrm{H}$ atoms were calculated geometrically and

Table 3 Crystal data, data collection and structure refinement for compounds $2 \mathbf{a}, 3 \mathbf{a}, 3 \mathbf{b}, \mathbf{4 b}$ and 5

\begin{tabular}{|c|c|c|c|c|c|}
\hline & $\mathbf{2 a}$ & $3 \mathbf{a}$ & $\mathbf{3 b}$ & $4 b$ & 5 \\
\hline Formula & $\mathrm{C}_{22} \mathrm{H}_{24} \mathrm{~N}_{4} \mathrm{Ag}, \mathrm{AgBr}_{2}$ & $\mathrm{C}_{11} \mathrm{H}_{12} \mathrm{~N}_{2} \mathrm{AuBr}$ & $\mathrm{C}_{17} \mathrm{H}_{16} \mathrm{~N}_{2} \mathrm{AuBr}$ & $\mathrm{C}_{17} \mathrm{H}_{16} \mathrm{~N}_{2} \mathrm{AuBr}_{3}$ & $\mathrm{C}_{11} \mathrm{H}_{12} \mathrm{~N}_{2} \mathrm{AuBrI} \mathrm{B}_{2}$ \\
\hline$M_{\mathrm{W}}$ & 719.99 & 449.10 & 525.19 & 685.01 & 702.90 \\
\hline Crystal size/mm & $0.06 \times 0.07 \times 0.09$ & $0.96 \times 0.75 \times 0.56$ & $0.85 \times 0.14 \times 0.12$ & $0.39 \times 0.20 \times 0.16$ & $0.20 \times 0.20 \times 0.18$ \\
\hline Crystal system & Triclinic & Orthorhombic & Tetragonal & Triclinic & Triclinic \\
\hline Space group & $P \overline{1}$ & $P 2_{1} 2_{1} 2_{1}$ & $P 4_{2} / n$ & $P \overline{1}$ & $P \overline{1}$ \\
\hline$a / \AA$ & $6.445(1)$ & $6.502(1)$ & $12.961(1)$ & $8.279(1)$ & $8.437(1)$ \\
\hline$b / \AA$ & $8.650(2)$ & $10.664(1)$ & 12.961(1) & $10.762(2)$ & $8.767(1)$ \\
\hline$c / \AA$ & $11.772(2)$ & $17.425(2)$ & $19.407(2)$ & $11.112(2)$ & $11.357(1)$ \\
\hline$\alpha\left(^{\circ}\right)$ & $69.05(3)$ & 90 & 90 & $98.946(5)$ & $94.81(1)$ \\
\hline$\beta\left(^{\circ}\right)$ & $85.31(3)$ & 90 & 90 & $92.925(4)$ & $98.10(1)$ \\
\hline$\gamma\left({ }^{\circ}\right)$ & $69.63(3)$ & 90 & 90 & $100.948(4)$ & $105.83(1)$ \\
\hline$V / \AA^{3}$ & $573.9(3)$ & $1204.9(3)$ & $3260.2(5)$ & $956.8(2)$ & $793.5(2)$ \\
\hline$\rho_{\mathrm{c}} / \mathrm{g} \mathrm{cm}^{-3}$ & 2.083 & 2.476 & 2.140 & 2.378 & 2.942 \\
\hline$Z$ & 1 & 4 & 8 & 2 & 2 \\
\hline$\mu / \mathrm{mm}^{-1}$ & 5.204 & 15.50 & 11.47 & 13.95 & 15.661 \\
\hline$T / \mathrm{K}$ & 293 & 300 & 200 & 200 & 123 \\
\hline$\theta$ range $\left[{ }^{\circ}\right]$ & $4.5-36.3$ & $3.0-25.1$ & $1.9-25.0$ & $2.9-25.0$ & $2.55-25.89$ \\
\hline Reflections collected & 5534 & 11033 & 20582 & 9393 & 6071 \\
\hline Unique reflections & 5534 & 2136 & 2887 & 3340 & 2870 \\
\hline Observed reflections $[I>2 \sigma(I)]$ & 5038 & 2011 & 2002 & 2666 & 2228 \\
\hline Parameters refined/restraint & $188 / 0$ & $137 / 0$ & $190 / 0$ & $208 / 0$ & $155 / 0$ \\
\hline Absorption correction & multi-scan & multi-scan & multi-scan & multi-scan & analytical \\
\hline$T_{\min }, T_{\max }$ & $0.652,0.745$ & $0.04,0.02$ & $0.04,0.34$ & $0.07,0.21$ & $0.0839,0.1547$ \\
\hline$\sigma_{\text {fin }}(\max / \min ) / \mathrm{e} \AA^{-3}$ & $5.48 /-2.48$ & $1.55 /-1.81$ & $1.36 /-0.84$ & $0.99 /-1.15$ & $1.981 /-0.860$ \\
\hline$R_{1}[I \geq 2 \sigma(I)]$ & 0.043 & 0.032 & 0.040 & 0.038 & 0.0298 \\
\hline$w R_{2}$ & 0.126 & 0.078 & 0.093 & 0.090 & 0.0764 \\
\hline CCDC number & 830315 & 830155 & 830156 & 830157 & 830158 \\
\hline
\end{tabular}


Table 4 Crystal data, data collection and structure refinement for compounds $6 \mathbf{a}, \mathbf{6 b}, 7 \mathbf{a}$, and $7 \mathbf{b}$

\begin{tabular}{|c|c|c|c|c|}
\hline & $6 a$ & $\mathbf{6 b}$ & $7 a$ & $7 b$ \\
\hline Formula & $\mathrm{C}_{22} \mathrm{H}_{24} \mathrm{~N}_{4} \mathrm{AuBr}$ & $\mathrm{C}_{34} \mathrm{H}_{32} \mathrm{~N}_{4} \mathrm{AuBr}$ & $\mathrm{C}_{22} \mathrm{H}_{24} \mathrm{~N}_{4} \mathrm{AuBr}_{3}$ & $\mathrm{C}_{34} \mathrm{H}_{32} \mathrm{~N}_{4} \mathrm{AuBr}_{3}, \mathrm{CH}_{2} \mathrm{Cl}_{2}$ \\
\hline$M_{\mathrm{W}}$ & 621.33 & 773.51 & 781.14 & 1018.23 \\
\hline Crystal system & Trigonal & Monoclinic & Monoclinic & Orthorhombic \\
\hline Space group & $R \overline{3} c$ & $P 2_{1} / c$ & $P 2_{1} / c$ & $P 2_{1} 2_{1} 2_{1}$ \\
\hline$a / \AA$ & $13.054(1)$ & $15.030(1)$ & $15.816(1)$ & $13.276(2)$ \\
\hline$b / \AA ̊$ & $13.054(1)$ & $11.044(1)$ & $9.941(1)$ & $14.874(2)$ \\
\hline$\beta\left(^{\circ}\right)$ & 90 & $128.227(3)$ & $109.15(1)$ & 90 \\
\hline$\gamma\left({ }^{\circ}\right)$ & 120 & 90 & 90 & 90 \\
\hline$V / \AA^{3}$ & $10095.9(2)$ & $2956.3(4)$ & $2376.3(4)$ & $3734.8(8)$ \\
\hline$\rho_{\mathrm{c}} / \mathrm{g} \mathrm{cm}^{-3}$ & 1.839 & 1.738 & 2.183 & 1.811 \\
\hline$Z$ & 18 & 4 & 4 & 4 \\
\hline$\mu / \mathrm{mm}^{-1}$ & 8.352 & 6.358 & 11.25 & 7.321 \\
\hline Parameters refined/restraint & $129 / 0$ & $361 / 0$ & $268 / 0$ & $393 / 0$ \\
\hline Absorption correction & multi-scan & multi-scan & analytical & multi-scan \\
\hline$T_{\min }, T_{\max }$ & $0.08,0.08$ & $0.07,0.15$ & $0.101,0.407$ & $0.120,0.220$ \\
\hline$\sigma_{\text {fin }}(\max / \min ) / \mathrm{e}^{-3}$ & $0.50,-0.64$ & $6.76,-4.71$ & $2.27,-0.73$ & $0.53,-0.48$ \\
\hline$R_{1}[I \geq 2 \sigma(I)]$ & 0.0233 & 0.075 & 0.028 & 0.031 \\
\hline$w R_{2}$ & 0.0442 & 0.191 & 0.067 & 0.068 \\
\hline CCDC number & 830159 & 830160 & 830161 & 830162 \\
\hline
\end{tabular}

a riding model was applied during the refinement process. Mass spectra were collected on a Finnigan LCQ DecaXPplus Ion trap Mass spectrometer with ESI ion source. The light sources were a $1000 \mathrm{~W}$ Hanovia Xe/Hg 977 B-1 lamp with a Schoeffel GM 250-1 monochromator and an Osram mercury short-arc lamp (HBO100W/2). The following compounds were prepared according to literature procedures: tetrahydrothiophene-gold(I)-bromide thtAuBr and tetrahydrothiophene-gold(I)-chloride thtAuCl, ${ }^{52}$ (1,3-dibenzylimidazol-2-ylidene)silver(I) bromide, $\mathbf{2 b}$. $^{20}$

The calculations were performed using the Turbomole program package ${ }^{53,54}$ version 6.1 . The potential energy scan was performed at the DFT level of theory using the BP86 ${ }^{55}$ functional Ahlrichs def2-SV $(\mathrm{P})^{56}$ basis sets the resolution-of-the-identity approximation (RI), as well as the multipole accelerated RI-J approximation, and in connection with an integration grid of $\mathrm{m} 4$ type and a setting of $\$$ denconv $=1.0 \mathrm{~d}-07$. The energy difference between the local minimum structure and the approximate transition state with an dihedral angle $\mathrm{Br}-\mathrm{Au}-\mathrm{C}-\mathrm{N}$ fixed at $180^{\circ}$, were recalculated with the PBE0 functional ${ }^{57}$ and the def2-TZVPP basis $^{58}$ set with relaxed geometries with and without the $\mathrm{COSMO}^{23}$ model.

1-Methyl-3-benzylimidazolium-bromide, 1a, was prepared according to a published procedure. ${ }^{59}$ Complementary ${ }^{13} \mathrm{C}\left\{{ }^{1} \mathrm{H}\right\}$ NMR data (125.8 MHz, DMSO- $\left.d_{6}, 30{ }^{\circ} \mathrm{C}\right): \delta=137.0$ (C2), 135.5 (ipso- $\left.\mathrm{C}_{\mathrm{Ph}}\right), 129.4,128.9\left(o-, m-\mathrm{C}_{\mathrm{Ph}}\right), 129.1\left(p-\mathrm{C}_{\mathrm{Ph}}\right), 124.4,122.7$ (C4/C5), $52.0\left(\mathrm{CH}_{2}\right), 36.4\left(\mathrm{CH}_{3}\right)$.

1,3-Dibenzylimidazolium-bromide, 1b. Sodium imidazolide (13.2 g, $0.15 \mathrm{~mol}$ ) and benzylbromide (50.2 g, $0.29 \mathrm{mmol})$ was refluxed in $250 \mathrm{~mL}$ toluene over night. The solvent was removed on a rotary evaporator and the residue was extracted with $\mathrm{DCM} / \mathrm{H}_{2} \mathrm{O}$. The organic phase was separated, dried with $\mathrm{Na}_{2} \mathrm{SO}_{4}$ and filtered. After the reduction of the volume the product was precipitated with $\mathrm{Et}_{2} \mathrm{O}$. Recrystallisation from $\mathrm{DCM} / \mathrm{Et}_{2} \mathrm{O}$ yielded the imidazolium bromide as a white powder. The analytical data correspond to the previously reported [20]. Complementary ${ }^{13} \mathrm{C}\left\{{ }^{1} \mathrm{H}\right\}$-NMR data $\left(125.8 \mathrm{MHz}\right.$, DMSO- $\left.d_{6}, 30{ }^{\circ} \mathrm{C}\right): \delta=136.7$ (C2), 135.3 (ipso- $\left.\mathrm{C}_{\mathrm{Ph}}\right), 129.4,129.2\left(o-, m-\mathrm{C}_{\mathrm{Ph}}\right), 128.9\left(p-\mathrm{C}_{\mathrm{Ph}}\right), 123.3$ (C4/C5), $52.4\left(\mathrm{CH}_{2}\right)$.

1-Methyl-3-benzylimidazol-2-ylidene-silver-bromide, 2a. A $100 \mathrm{ml}$ round bottom flask was covered with aluminium foil and charged with the imidazolium bromide 1a (1.04 g, $4.11 \mathrm{mmol})$ and $20 \mathrm{ml} \mathrm{DCM}$. To the resulting solution was added dry $\operatorname{Ag}_{2} \mathrm{O}$ $(0.48 \mathrm{~g}, 2.05 \mathrm{mmol})$. After an overall stirring time of $3 \mathrm{~h}$ at ambient temperature the reaction mixture was filtered over Celite. The solvent was removed in vacuo and recrystallization from $\mathrm{DCM} / \mathrm{Et}_{2} \mathrm{O}$ giving the products as colourless powders. Yield: $1.02 \mathrm{~g}(80 \%) ;{ }^{1} \mathrm{H}-\mathrm{NMR}\left(200 \mathrm{MHz}, \mathrm{DMSO}-d_{6}, 30{ }^{\circ} \mathrm{C}\right): \delta=7.48$ $\left(\mathrm{d},{ }^{3} J_{\mathrm{HH}}=1.64 \mathrm{~Hz}, \operatorname{Im} H, 1 \mathrm{H}\right), 7.40\left(\mathrm{~d},{ }^{3} J_{\mathrm{HH}}=1.67 \mathrm{~Hz}, \operatorname{Im} H, 1 \mathrm{H}\right)$, 7.28 (m, Ph, 5H), 5.27 (s, $\left.\mathrm{CH}_{2}, 2 \mathrm{H}\right), 3.73\left(\mathrm{~s}, \mathrm{CH}_{3}, 3 \mathrm{H}\right) ;{ }^{13} \mathrm{C}\left\{{ }^{1} \mathrm{H}\right\}$ NMR data $\left(125.8 \mathrm{MHz}, \mathrm{DMSO}-d_{6}, 30^{\circ} \mathrm{C}\right): \delta=180.7(\mathrm{C} 2), 137.8$ $\left(\right.$ ipso- $\left.\mathrm{C}_{\mathrm{Ph}}\right), 129.2,128.1\left(o-, m-\mathrm{C}_{\mathrm{Ph}}\right), 128.2\left(p-\mathrm{C}_{\mathrm{Ph}}\right), 123.7,122.6$ (C4/C5), $54.4\left(\mathrm{CH}_{2}\right), 38.6\left(\mathrm{CH}_{3}\right)$; EA: calcld for $\mathrm{C}_{11} \mathrm{H}_{12} \mathrm{~N}_{2} \mathrm{AgBr}$ (360.00): C 36.70, H 3.36, N 7.78. Found: C 36.87, H 3.52, N 7.98.

1-Methyl-3-benzylimidazol-2-ylidene-gold-bromide, 3a. To a solution of thtAuBr $(0.17 \mathrm{~g}, 0.45 \mathrm{mmol})$ in $10 \mathrm{~mL} \mathrm{DCM}$ was added 2a ( $0.20 \mathrm{~g}, 1.79 \mathrm{mmol})$, whereby $\mathrm{AgBr}$ was precipitating immediately. After further stirring for $3 \mathrm{~h}$ at ambient temperature the solvent was removed in vacuo and the remaining solid was extracted with DCM. The product could be isolated by precipitation with $\mathrm{Et}_{2} \mathrm{O}$. Yield: $0.12 \mathrm{~g}(48 \%) .{ }^{1} \mathrm{H}-\mathrm{NMR}(200 \mathrm{MHz}$, DMSO- $\left.d_{6}, 30^{\circ} \mathrm{C}\right): \delta=7.49\left(\mathrm{~d},{ }^{3} J_{\mathrm{HH}}=1.88 \mathrm{~Hz}, \operatorname{Im} H, 1 \mathrm{H}\right), 7.42(\mathrm{~d}$, $\left.{ }^{3} J_{\mathrm{HH}}=1.88 \mathrm{~Hz}, \mathrm{Im} H, 1 \mathrm{H}\right), 7.32(\mathrm{br}, \mathrm{Ph}, 5 \mathrm{H}), 5.29\left(\mathrm{~s}, \mathrm{CH}_{2}, 2 \mathrm{H}\right)$, $3.72\left(\mathrm{~s}, \mathrm{CH}_{3}, 3 \mathrm{H}\right) ;{ }^{13} \mathrm{C}\left\{{ }^{1} \mathrm{H}\right\}-\mathrm{NMR}\left(125.8 \mathrm{MHz}, \mathrm{DMSO}-d_{6}, 30{ }^{\circ} \mathrm{C}\right)$ : 
$\delta=172.7(\mathrm{~s}, \mathrm{C} 2), 137.7\left(\mathrm{~s}\right.$, ipso- $\left.\mathrm{C}_{\mathrm{Ph}}\right), 129.2,128.5,128.0(\mathrm{~s}, \mathrm{Ph})$, 123.6, 122.0 (s, ImC4/5), 53.9 (s, $\left.\mathrm{CH}_{2}\right), 38.0$ (s, $\left.\mathrm{CH}_{3}\right)$; EA: calcld for $\mathrm{C}_{11} \mathrm{H}_{12} \mathrm{~N}_{2} \mathrm{AuBr}$ (449.10): C 29.42, H 2.69, N 6.24. Found: C 29.29, H 2.67, N 6.19.

1,3-Dibenzylimidazol-2-ylidene-gold-bromide, 3b. The complex was prepared analogues to 3a: Starting materials: 2 b (0.232 $\mathrm{g}, 0.531 \mathrm{mmol})$, thtAuBr $(0.194 \mathrm{~g}, 0.530 \mathrm{mmol})$. Yield $0.18 \mathrm{~g}$ $(61 \%) .{ }^{1} \mathrm{H}-\mathrm{NMR}\left(200 \mathrm{MHz}, \mathrm{DMSO}-\mathrm{d}_{6}, 30{ }^{\circ} \mathrm{C}\right): \delta=7.56(\mathrm{~s}, \mathrm{ImH}$, 2H), 7.31-7.36 (m, Ph, 10H), $5.34\left(\mathrm{~s}, \mathrm{CH}_{2}, 4 \mathrm{H}\right) ;{ }^{13} \mathrm{C}\left\{{ }^{1} \mathrm{H}\right\}-\mathrm{NMR}$ $\left(125.8 \mathrm{MHz}, \mathrm{DMSO}-\mathrm{d}_{6}, 30{ }^{\circ} \mathrm{C}\right): \delta=169.1(\mathrm{~s}, \mathrm{C} 2), 136.6$ (s, ipso$\mathrm{C}_{\mathrm{Ph}}$ ), 128.8, 128.1, 127.6 (s, Ph), 122.3 (s, ImC4/5), 53.8 (s, $\mathrm{CH}_{2}$ ); EA: calcld for $\mathrm{C}_{17} \mathrm{H}_{16} \mathrm{~N}_{2} \mathrm{AuBr}$ (525.20): C 38.88, H 3.07, N 5.33. Found: C 38.83, H 3.05, N 5.34.

1-Methyl-3-benzylimidazol-2-ylidene-gold-tribromide, 4a. The gold(III) complexes were prepared analogous to a published procedure: ${ }^{9 b}$ A solution of $\mathrm{Br}_{2}(8 \mathrm{mg}, 53 \mu \mathrm{mol})$ in DCM was added to a solution of $\mathbf{3 a}(24 \mathrm{mg}, 53 \mu \mathrm{mol})$ at $-40{ }^{\circ} \mathrm{C}$. The solution is allowed to warm to room temperature and stirred for another $12 \mathrm{~h}$ in the dark. The solvent was removed under reduced pressure and the residue was dissolved in a minimum of DCM. The yellow product was precipitated with pentane, isolated by filtration and dried in vacuo. Yield: $19 \mathrm{mg}(62 \%) .{ }^{1} \mathrm{H}-\mathrm{NMR}(200 \mathrm{MHz}, \mathrm{DMSO}-$ $\left.d_{6}, 30{ }^{\circ} \mathrm{C}\right): \delta=7.73\left(\mathrm{~d},{ }^{3} J_{\mathrm{HH}}=1.93 \mathrm{~Hz}, \operatorname{Im} H, 1 \mathrm{H}\right), 7.70\left(\mathrm{~d},{ }^{3} J_{\mathrm{HH}}=\right.$ $2.08 \mathrm{~Hz}, \operatorname{Im} H, 1 \mathrm{H}), 7.34(\mathrm{~m}, \mathrm{Ph}, 5 \mathrm{H}), 5.40\left(\mathrm{~s}, \mathrm{CH}_{2}, 2 \mathrm{H}\right), 3.79$ (s, $\left.\mathrm{CH}_{3}, 3 \mathrm{H}\right) ;{ }^{13} \mathrm{C}\left\{{ }^{1} \mathrm{H}\right\}-\mathrm{NMR}\left(125.8 \mathrm{MHz}, \mathrm{DMSO}-d_{6}, 30{ }^{\circ} \mathrm{C}\right)$ : $\delta=134.6(\mathrm{~s}, \mathrm{C} 2), 136.1$ (s, ipso- $\left.\mathrm{C}_{\mathrm{Ph}}\right), 128.9,128.7,128.2(\mathrm{~s}, \mathrm{Ph})$, 125.0, 122.8 (s, ImC4/5), $51.9\left(\mathrm{~s}, \mathrm{CH}_{2}\right), 39.0\left(\mathrm{~s}, \mathrm{CH}_{3}\right)$; EA calcld for $\mathrm{C}_{11} \mathrm{H}_{12} \mathrm{~N}_{2} \mathrm{AuBr}_{3}$ (608.91): C 21.70, $\mathrm{H} \mathrm{1.99,} \mathrm{N} \mathrm{4.60.} \mathrm{Found:} \mathrm{C}$ 21.80, H 2.08, N 4.61; MS (ESI, $\mathrm{CHCl}_{3} / \mathrm{MeCN}$ ): $m / z=541.33$ $\mathrm{L}_{2} \mathrm{Au}^{+}$.

1,3-Dibenzylimidazol-2-ylidene-gold-tribromide, 4b. The complex 4b was prepared analogues to 4a: Starting materials: $3 \mathbf{b}(0.112$ $\mathrm{g}, 0.213 \mathrm{mmol}), \mathrm{Br}_{2}(0.034 \mathrm{~g}, 0.212 \mathrm{mmol})$. Yield $0.071 \mathrm{~g}(49 \%)$. ${ }^{1} \mathrm{H}-\mathrm{NMR}\left(200 \mathrm{MHz}, \mathrm{DMSO}-d_{6}, 30{ }^{\circ} \mathrm{C}\right): \delta=7.73(\mathrm{~s}, \mathrm{Im} H, 2 \mathrm{H})$, $7.35(\mathrm{~m}, \mathrm{Ph}, 10 \mathrm{H}), 5.42\left(\mathrm{~s}, \mathrm{CH}_{2}, 4 \mathrm{H}\right) ;{ }^{13} \mathrm{C}\left\{{ }^{1} \mathrm{H}\right\}-\mathrm{NMR}(125.8 \mathrm{MHz}$, DMSO $\left.-d_{6}, 30^{\circ} \mathrm{C}\right): \delta=136.3(\mathrm{C} 2), 134.3\left(\mathrm{~s}\right.$, ipso- $\left.\mathrm{C}_{\mathrm{Ph}}\right), 128.9,128.7$, 128.6 (s, Ph), 125.2 (s, ImC4/5), $53.7\left(\mathrm{~s}, \mathrm{CH}_{2}\right)$; EA calcld for $\mathrm{C}_{17} \mathrm{H}_{16} \mathrm{~N}_{2} \mathrm{AuBr}_{3}$ (685.01): C 29.81, H 2.35, N 4.09. Found: C 29.89, $\mathrm{H} 2.40, \mathrm{~N} 4.01 ; \mathrm{MS}$ (ESI, $\mathrm{CHCl}_{3} / \mathrm{CH}_{3} \mathrm{OH} / \mathrm{NH}_{4} \mathrm{Ac}$ ): $m / z=684.07$ $\mathrm{M}^{+}, 693.4 \mathrm{~L}_{2} \mathrm{Au}^{+}$.

1-Methyl-3-benzylimidazol-2-ylidene-gold-dibromide-iodide, 5 . To a solution of $\mathbf{3 a}(0.20 \mathrm{~g}, 0.32 \mathrm{mmol})$ in $50 \mathrm{~mL}$ DCM was added at $-40{ }^{\circ} \mathrm{C}$ under stirring iodine $(0.09 \mathrm{~g}, 0.32 \mathrm{mmol})$. The solution was allowed to warm to room temperature and stirred for another $2 \mathrm{~h}$. The solution was filtered over Celite and the solvent was removed under reduced pressure. The residue was dissolved in a minimum of DCM and precipitated with $\mathrm{Et}_{2} \mathrm{O}$ as a brown powder. Yield: $0.20 \mathrm{~g}(89 \%) .{ }^{1} \mathrm{H}-\mathrm{NMR}\left(200 \mathrm{MHz}, \mathrm{DMSO}-d_{6}, 30^{\circ} \mathrm{C}\right): \delta=$ 7.66 (s, ImH, 2H), 7.42 (m, Ph, 5H), 5.42 (s, $\left.\mathrm{CH}_{2}, 2 \mathrm{H}\right), 3.85$ (s, $\mathrm{CH}_{3}, 3 \mathrm{H}$ ); EA: calcld for $\mathrm{C}_{11} \mathrm{H}_{12} \mathrm{~N}_{2} \mathrm{AuBrI}_{2}$ (702.90): $\mathrm{C} 18.80 \mathrm{H}$ 1.72 N 3.99. Found: C 18.89 H 1.81 N 4.01.

Bis(1-methyl-3-benzylimidazol-2-ylidene)gold-bromide, $\quad 6$ a. The ionic gold complexes were prepared according to a modified literature procedure: ${ }^{7 f}$ In a glove box, a solution of LiHMDS (70 $\mathrm{mg}, 0.39 \mathrm{mmol}$ ) in $5 \mathrm{~mL}$ DCM was added to a solution of 1a $(0.10 \mathrm{mg}, 0.40 \mathrm{mmol})$ in $5 \mathrm{~mL}$ DCM and stirred for
$10 \mathrm{~min}$. To this solution thtAuBr $(70 \mathrm{mg}, 0.20 \mathrm{mmol})$ in 10 $\mathrm{mL}$ DCM was added and stirred for $2 \mathrm{~h}$. Outside the glove box the reaction was quenched with $10 \mathrm{~mL}$ water. The DCM phase was separated, dried with $\mathrm{Na}_{2} \mathrm{SO}_{4}$ and the solvent was removed in vacuo. Recrystallisation from $\mathrm{DCM} / \mathrm{Et}_{2} \mathrm{O}$ yielded 6a as a white powder. Yield $60 \mathrm{mg}(48 \%) .{ }^{1} \mathrm{H}-\mathrm{NMR}(200 \mathrm{MHz}$, DMSO- $\left.d_{6}, 30{ }^{\circ} \mathrm{C}\right): \delta=7.57\left(\mathrm{~d},{ }^{3} J_{\mathrm{HH}}=1.74 \mathrm{~Hz}, \operatorname{Im} H, 2 \mathrm{H}\right), 7.48$ $\left(\mathrm{d},{ }^{3} J_{\mathrm{HH}}=1.62 \mathrm{~Hz}, \mathrm{Im} H, 2 \mathrm{H}\right), 7.27(\mathrm{~m}, \mathrm{Ph}, 10 \mathrm{H}), 5.33\left(\mathrm{~s}, \mathrm{CH}_{2}\right.$, $4 \mathrm{H}), 3.77\left(\mathrm{~s}, \mathrm{CH}_{3}, 6 \mathrm{H}\right) ;{ }^{13} \mathrm{C}\left\{{ }^{1} \mathrm{H}\right\}-\mathrm{NMR}\left(125.8 \mathrm{MHz}, \mathrm{DMSO}-d_{6}\right.$, $\left.30{ }^{\circ} \mathrm{C}\right): \delta=186.4$ (s, C2), 140.4 (s, ipso- $\mathrm{C}_{\mathrm{Ph}}$ ), 132.1, 131.4, 130.8 (s, Ph), 127.1, 125.9 (s, ImC4/5), $56.8\left(\mathrm{~s}, \mathrm{CH}_{2}\right), 40.9\left(\mathrm{~s}, \mathrm{CH}_{3}\right)$; EA: calcld for $\mathrm{C}_{22} \mathrm{H}_{24} \mathrm{~N}_{4} \mathrm{AuBr}$ (621.33): C 42.49, H 3.89, N 9.01. Found: C 42.47, $\mathrm{H}$ 3.88, $\mathrm{N}$ 8.98; $\mathrm{MS}$ (ESI, $\mathrm{MeCN} / \mathrm{H}_{2} \mathrm{O}$ ): $m / z$ : $541.33 \mathrm{M}^{+}$

Bis(1,3-dibenzylimidazol-2-ylidene)gold-bromide, 6b. Complex $\mathbf{6 b}$ was prepared from $\mathbf{1 b}(0.23 \mathrm{~g}, 0.68 \mathrm{mmol})$, LiHMDS $(0.14 \mathrm{~g}, 0.86 \mathrm{mmol})$, and tht $\mathrm{AuBr}(0.13 \mathrm{~g}, 0.34 \mathrm{mmol})$ using the method described for 6a. Yield: $0.16 \mathrm{~g}(53 \%) .{ }^{1} \mathrm{H}-\mathrm{NMR}(200 \mathrm{MHz}$, DMSO- $\left.d_{6}, 30^{\circ} \mathrm{C}\right): \delta=7.62(\mathrm{~s}, \mathrm{Im} H, 4 \mathrm{H}), 7.19-7.26(\mathrm{~m}, \mathrm{Ph}, 20 \mathrm{H})$, $5.32\left(\mathrm{~s}, \mathrm{CH}_{2}, 8 \mathrm{H}\right) ;{ }^{13} \mathrm{C}\left\{{ }^{1} \mathrm{H}\right\}-\mathrm{NMR}\left(125.8 \mathrm{MHz}\right.$, DMSO- $\left.d_{6}, 30{ }^{\circ} \mathrm{C}\right)$ : $\delta=182.9$ (s, C2), 136.8 (s, ipso- $\left.\mathrm{C}_{\mathrm{Ph}}\right), 128.7,128.1,127.3(\mathrm{~s}, \mathrm{Ph})$, 123.0 (s, ImC4/5), 53.6 (s, $\mathrm{CH}_{2}$ ); EA: calcld for $\mathrm{C}_{34} \mathrm{H}_{32} \mathrm{~N}_{4} \mathrm{AuBr}$ (773.53): C 52.79, H 4.17, N 7.24. Found: C 52.57, H 4.10, N 7.03; MS (ESI, $\left.\mathrm{CHCl}_{3} / \mathrm{MeCN}\right): m / z=693.32 \mathrm{M}^{+}$.

Bis(1,3-dibenzylimidazol-2-ylidene)gold-chloride, 6c. Complex 6c was prepared analogues to $\mathbf{6 b}$ by using tht $\mathrm{AuCl}$ instead of thtAuBr. Yield: $72 \%$. NMR data are identical within experimental error. EA: calcld for $\mathrm{C}_{34} \mathrm{H}_{32} \mathrm{~N}_{4} \mathrm{AuCl}$ (729.07): $\mathrm{C} 56.01, \mathrm{H} 4.42, \mathrm{~N}$ 7.68. Found: C 56.12, H 4.29, N 7.63.

Bis(1-methyl-3-benzylimidazol-2-ylidene)gold-tribromide, 7a. Complex 7a was prepared by the procedure described for $\mathbf{4 a}$. The ionic complexes $7 \mathbf{a}$ and $\mathbf{7 b}$ are sparingly soluble in acetone and can easily be purified by washing with acetone. Starting materials: 6a $(0.20 \mathrm{~g}, 0.33 \mathrm{mmol}), \mathrm{Br}_{2}(62 \mathrm{mg}, 0.39 \mathrm{mmol})$. Yield: $0.21 \mathrm{~g}$ $(81 \%)$.

Anti-isomer: ${ }^{1} \mathrm{H}-\mathrm{NMR}\left(500 \mathrm{MHz}, \mathrm{d}_{6}-\mathrm{DMSO}, 30{ }^{\circ} \mathrm{C}\right): \delta 7.76(\mathrm{~d}$, $\left.{ }^{3} J_{\mathrm{HH}}=1.6 \mathrm{~Hz}, 2 \mathrm{H}, \mathrm{CH}_{\mathrm{Im}}\right), 7.75\left(\mathrm{~d},{ }^{3} J_{\mathrm{HH}}=1.6 \mathrm{~Hz}, 2 \mathrm{H}, \mathrm{CH}_{\mathrm{Im}}\right)$, $7.40\left(\mathrm{~m}, 6 \mathrm{H}, \mathrm{CH}_{\mathrm{Ph}}\right), 7.30\left(\mathrm{~d}, 4 \mathrm{H}, \mathrm{CH}_{\mathrm{Ph}}\right), 5.52\left(\mathrm{~s}, 4 \mathrm{H},-\mathrm{CH}_{2}\right), 3.68$ (s, $6 \mathrm{H},-\mathrm{CH}_{3}$ ). Syn-isomer: $\delta 7.77\left(\mathrm{~d},{ }^{3} J_{\mathrm{HH}}=1.65 \mathrm{~Hz}, 2 \mathrm{H}, \mathrm{CH}_{\mathrm{Im}}\right)$, $7.68\left(\mathrm{~d},{ }^{3} J_{\mathrm{HH}}=1.65 \mathrm{~Hz}, 2 \mathrm{H}, \mathrm{CH}_{\mathrm{Im}}\right), 7.28\left(\mathrm{~m}, 6 \mathrm{H}, \mathrm{CH}_{\mathrm{Ph}}\right), 7.21(\mathrm{~d}$, $\left.4 \mathrm{H}, \mathrm{CH}_{\mathrm{Ph}}\right), 5.33\left(\mathrm{~s}, 4 \mathrm{H}, \mathrm{CH}_{2}\right), 3.68\left(\mathrm{~s}, 6 \mathrm{H}, \mathrm{CH}_{3}\right)$. Anti-isomer: ${ }^{13} \mathrm{C}-\mathrm{NMR}\left(125.8 \mathrm{MHz}, \mathrm{d}_{6}\right.$-DMSO, $\left.30{ }^{\circ} \mathrm{C}\right): \delta: 149.7$ (C2), 135.5 (ispo- $\left.\mathrm{C}_{\mathrm{Ph}}\right), 128.4\left(\mathrm{C}_{\mathrm{Ph}}\right), 126.1\left(\mathrm{C}_{\mathrm{Ph}}\right), 125.6\left(\mathrm{CH}_{\mathrm{Im}}\right), 124.9\left(\mathrm{CH}_{\mathrm{Im}}\right)$, $53.1\left(\mathrm{CH}_{2}\right), 37.31\left(\mathrm{CH}_{3}\right)$. Syn-isomer: $\delta 149.8(\mathrm{C} 2)$, 135.3 (ipso$\left.\mathrm{C}_{\mathrm{Ph}}\right), 128.4\left(\mathrm{C}_{\mathrm{Ph}}\right), 127.7\left(\mathrm{C}_{\mathrm{Ph}}\right), 125.9\left(\mathrm{CH}_{\mathrm{Im}}\right), 124.4\left(\mathrm{CH}_{\mathrm{Im}}\right), 52.9$ $\left(\mathrm{CH}_{2}\right), 37.3\left(-\mathrm{CH}_{3}\right)$; EA: calcld for $\mathrm{C}_{22} \mathrm{H}_{24} \mathrm{~N}_{4} \mathrm{AuBr}_{3}$ (781.14): C 33.83, H 3.10, N 7.17. Found: C 33.57, H 2.89, N 7.01, MS (ESI, $\left.\mathrm{CHCl}_{3} / \mathrm{CH}_{3} \mathrm{OH}\right): m / z=701 \mathrm{M}^{+}, 542.33 \mathrm{~L}_{2} \mathrm{Au}^{+}$.

Bis(1,3-dibenzylimidazol-2-ylidene)gold-tribromide, 7b. Complex $\mathbf{7 b}$ was prepared by the procedure described for $\mathbf{4 a}$. Starting materials: 6b (70 mg, $91 \mu \mathrm{mol}), \mathrm{Br}_{2}(14 \mathrm{mg}, 90 \mu \mathrm{mol})$. Yield: $48 \mathrm{mg}$ $(58 \%) .{ }^{1} \mathrm{H}-\mathrm{NMR}\left(200 \mathrm{MHz}, \mathrm{DMSO}-d_{6}, 30{ }^{\circ} \mathrm{C}\right): \delta=7.67(\mathrm{~s}, \operatorname{Im} H$, 4H), 7.12-7.27 (m, Ph, 20H), $5.30\left(\mathrm{~s}, \mathrm{CH}_{2}, 8 \mathrm{H}\right) ;{ }^{13} \mathrm{C}\left\{{ }^{1} \mathrm{H}\right\}-\mathrm{NMR}$ $\left(125.8 \mathrm{MHz}, \mathrm{DMSO}-d_{6}, 30{ }^{\circ} \mathrm{C}\right): \delta=150.1$ (s, C2) 135.1 (s, ipso$\left.\mathrm{C}_{\mathrm{Ph}}\right), 129.3,128.9,128.1(\mathrm{~s}, \mathrm{Ph}), 125.8(\mathrm{~s}, \mathrm{ImC} 4 / 5), 53.8\left(\mathrm{~s}, \mathrm{CH}_{2}\right)$; EA calcld for $\mathrm{C}_{34} \mathrm{H}_{32} \mathrm{~N}_{4} \mathrm{AuBr}_{3}$ (933.33):C 43.75, H 3.46, N 6.00. 
Found: C 43.48, H 3.47, N 6.22; MS (ESI, $\mathrm{MeCN} / \mathrm{H}_{2} \mathrm{O}$ ): $m / z=$ $853.08 \mathrm{M}^{+}, 693.42 \mathrm{~L}_{2} \mathrm{Au}^{+}$.

Bis(1,3-dibenzylimidazol-2-ylidene)gold-dibromide-chloride, 7c. Complex 7c was prepared analogues to $\mathbf{7 b}$ by using $\mathbf{6 c}$ instead of $\mathbf{6 b}$. Yield: $79 \%$. NMR data are identical within experimental error. EA: calcld for $\mathrm{C}_{34} \mathrm{H}_{32} \mathrm{~N}_{4} \mathrm{AuBr}_{2} \mathrm{Cl}$ (888.88): C 45.94, $\mathrm{H}$ 3.63, N 6.30. Found: C 46.12, H 3.71, N 6.53.

General procedure for the reactions of gold(III) bromides $4 \mathrm{~b}$ and $7 \mathbf{b}$ with various ligands. $4 \mathbf{b}(0.05 \mathrm{~g}, 0.08 \mathrm{mmol})$ or $7 \mathbf{c}(0.05$ g, $0.06 \mathrm{mmol})$ were suspended in $20 \mathrm{~mL}$ absolute acetone and cooled to $-40{ }^{\circ} \mathrm{C}$. To this mixture 3 (for $\mathbf{4 b}$ ) or 2 (for $7 \mathbf{c}$ ) equivalents of $\mathrm{AgNO}_{3}, \mathrm{Ag}$ (acetate), $\mathrm{Ag}_{2}$ (oxalate), and $\mathrm{Ag}$ (benzoate), or a mixture of $\mathrm{AgBF}_{4} / \mathrm{Na}(\mathrm{OPh}), \mathrm{AgBF}_{4} / \mathrm{Na}\left(\mathrm{OC}_{6} \mathrm{Cl}_{5}\right)$, and $\mathrm{AgBF}_{4} / \mathrm{Na}(\mathrm{SPh})$ were added. After the reaction mixtures were allowed to warm to room temperature it was stirred for additional 4h. The formed $\mathrm{AgBr} / \mathrm{Cl}$ was removed by filtration over Celite and the solvent was distilled off in a vacuo. The residues were dissolved in a minimum of DCM and crystallized by slow gas phase diffusion of $\mathrm{Et}_{2} \mathrm{O}$.

\section{Acknowledgements}

We thank Prof. G. Knör for fruitful discussions and generous support of the experimental work.

\section{References}

1 (a) J. G. Garrison and W. J. Youngs, Chem. Rev., 2005, 105, 3978-4008; (b) J. C. Y. Lin, R. T. W. Huang, C. S. Lee, A. Bhattacharyya, W. S. Hwang and I. J. B. Lin, Chem. Rev., 2009, 109, 3561-3598; (c) I. J. B. Lin and C. S. Vasam, Can. J. Chem., 2005, 83, 812-825.

2 H. M. J. Wang and I. J. B. Lin, Organometallics, 1998, 17, 972-975.

3 K. M. Lee, H. M. J. Wang and I. J. B. Lin, J. Chem. Soc., Dalton Trans., 2002, 2852-2856.

4 (a) W. Chen and F. Liu, J. Organomet. Chem., 2003, 673, 5-12; (b) P. de Frémont, N. M. Scott, E. D. Stevens, T. Ramnial, O. C. Lightbody, C L. B. Macdonald, J. A. Clyburne, C. D. Abernethy and S. P. Nolan, Organometallics, 2005, 24, 6301-6309.

5 (a) X. Zeng, R. Kinjo, B. Donnadieu and G. Bertrand, Angew. Chem., 2010, 122, 954-957; , Angew. Chem., Int. Ed., 2010, 49, 942-945; (b) A. S. K. Hashmi, A. M. Schuster and F. Rominger, Angew. Chem., 2009, 121, 8396-8398; , Angew. Chem., Int. Ed., 2009, 48, 8247-8249; (c) N. Marion, R. S. Ramón and S. P. Nolan, J. Am. Chem. Soc., 2009, 131, 448-449; (d) N. Marion, G. Lemiére, A. Correa, C. Costabile, R. S. Ramón, X. Moreau, P. de Frémont, R. Dahmane, A. Hours, D. Lesage, J.-C. Tabet, J.-P. Goddard, V. Gandon, L. Cavallo, L. Fensterbank, M. Malacria and S. P. Nolan, Chem.-Eur. J., 2009, 15, 3243-3260; (e) R. S. Paton and F. Maseras, Org. Lett., 2009, 11, 2237-2240; (f) S. DíezGonzález, N. Marion and S. P. Nolan, Chem. Rev., 2009, 109, 36123676; $(g)$ J. Urbano, A. J. Hormigo, P. de Frémont, S. P. Nolan, M. M. Díaz-Requejo and P. J. Pérez, Chem. Commun., 2008, 759-761; (h) N. Marion and S. P. Nolan, Chem. Soc. Rev., 2008, 37, 1776-1782; (i) N. Marion, P. Carlqvist, R. Gealageas, P. de Frémont, F. Maseras and S. P. Nolan, Chem.-Eur. J., 2007, 13, 6437-6451; (j) S. M. Kim, J. H. Park, S. Y. Choi and Y. K. Chung, Angew. Chem., Int. Ed., 2007, 46, 6172-6275.

6 M. Pažický, A. Loos, M. J. Ferreira, D. Serra, N. Vinokurov, F. Rominger, C. Jäkel, A S. K. Hashmi and M. Limbach, Organometallics, 2010, 29, 4448-4458.

7 (a) P. de Frémont, N. Marion and S. P. Nolan, J. Organomet. Chem., 2009, 694, 551-560; (b) H. G. Raubenheimer and S. Cronje, Chem. Soc. Rev., 2008, 37, 1998-2011; (c) J. L. Hickey, R. A. Ruhayel, P. J. Barnard, M. V. Baker, S. J. Berners-Price and A. Filipovska, J. Am. Chem. Soc., 2008, 130, 12570-12571; (d) M. M. Jellicoe, S. J. Nichols, B. A. Callus, M. V. Baker, P. J. Barnard, S. J. Berners-Price, J. Whelan, G. C. Yeoh and A. Filipovska, Carcinogenesis, 2008, 29, 1124-1133; (e) I. J. Lin and C. S. Vasam, Coord. Chem. Rev., 2007, 251, 642-670; ( $f$ ) M. V. Baker, P. J. Barnard, S. J. Berners-Price, S. K. Brayshaw, J. L. Hickey,
B. W. Skelton and A. H. White, Dalton Trans., 2006, 3708-3715; (g) M. V. Baker, P. J. Barnard, S. J. Berners-Price, S. K. Brayshaw, J. L. Hickey, B. W. Skelton and A. H. White, J. Organomet. Chem., 2005, 690, 56255635; (h) P. J. Barnard, M. V. Baker, S. J. Berners-Price and D. A. Day, J. Inorg. Biochem., 2004, 98, 1642-1647; (i) J. Weaver, S. Gaillard, C. Toye, S. Macpherson, S. P. Nolan and A. Riches, Chem.-Eur. J., 2011, 17, 6620-6624.

8 J. Lemke, A. Pinto, P. Niehoff, V. Vasylyeva and N. Metzler-Nolte, Dalton Trans., 2009, 7063-7070.

9 (a) S. Gaillard, A. M. Z. Slawin, A. T. Bonura, E. D. Stevens and S. P. Nolan, Organometallics, 2010, 29, 394-402; (b) M. C. Jahnke, T. Pape and F. E. Z. Hahn, Z. Anorg. Allg. Chem., 2010, 636, 2309-2314; (c) S. Gaillard, X. Bantreil, A. M. Z. Slawin and S. P. Nolan, Dalton Trans., 2009, 6967-6971; (d) R. Jothibasu, H. V. Huynh and L. L. Koh, J. Organomet. Chem., 2008, 693, 374-380; (e) P. de Frémont, R. Singh, E. D. Stevens, J. L. Petersen and S. P. Nolan, Organometallics, 2007, 26, 1376-1385; $(f)$ H. G. Raubenheimer, P. J. Olivier, L. Lindeque, M. Desmet, J. Hrusak and G. J. Kruger, J. Organomet. Chem., 1997, 544, 91-100; $(g)$ P. Kühlkamp, H. G. Raubenheimer, J. S. Field and M. Desmet, J. Organomet. Chem., 1998, 552, 69-74.

10 (a) M. K. Samantaray, K. Pang, M. M. Shaikh and P. Gosh, Dalton Trans., 2008, 4893-4902; (b) F. J.-B. d. Dominique, H. Gornitzka, A. Sournia-Saquet and C. Hemmert, Dalton Trans., 2009, 340-352.

11 V. J. Scott, J. A. Labinger and J. E. Bercaw, Organometallics, 2010, 29, 4090-4096.

12 M. Boronat, A. Corma, C. González-Arellano, M. Iglesias and F. Sanchez, Organometallics, 2010, 29, 134-141.

13 (a) N. Komine, K. Ichikawa, A. Mori, M. Hirano and S. Komiya, Chem. Lett., 2005, 34, 1704-1705; (b) A. Tamaki and J. K. Kochi, J. Organomet. Chem., 1973, 64, 411-425; (c) R. E. Bachman, S. A. Bodolosky-Bettis, C. J. Pyle and M. Anne Gray, J. Am. Chem. Soc., 2008, 130, 14303-14310.

14 (a) A. Vogler and H. Kunkely, Coord. Chem. Rev., 2001, 219-221, 489507 and references therein; (b) I. M. Serafimova and P. E. Hoggard, Inorg. Chim. Acta, 2002, 338, 105.

15 (a) B. S. Maritz and R. van Eldik, J. Inorg. Nucl. Chem., 1976, 38, 2124-2125; (b) K. Kurihara, J. Kizling, P. Stenius and J. H. Fendler, J. Am. Chem. Soc., 1983, 105, 2574-2579; (c) L. R. Cohen, L. A. Pena, A. J. Seidl, J. M. Olsen, J. Wekselbaum and P. E. Hoggard, Monatsh. Chem., 2009, 140, 1159-1165 and references therein.

16 H. Kunkely and A. Vogler, Inorg. Chem., 1992, 31, 4539-4541.

17 T. S. Teets and D. G. Nocera, J. Am. Chem. Soc., 2009, 131, 7411-7420.

18 V. Balzani and V. Carassiti, in Photochemistry of Coordination Compounds, Academic Press, London, 1970.

19 W. A. Herrmann, O. Runte and G. Artus, J. Organomet. Chem., 1995, 501, $\mathrm{Cl}-\mathrm{C} 4$.

20 J. Berding, H. Kooijman, A. L. Spek and E. Bouwman, J. Organomet. Chem., 2009, 694, 2217-2221.

21 (a) H. V. Huynh and J. Wu, J. Organomet. Chem., 2009, 694, $323-$ 331; (b) C. P. Newman, R. J. Deeth, G. J. Clarkson and J. P. Rourke, Organometallics, 2007, 26, 6225-6233.

$2219.1 \times 10^{-3} \times T_{c}\left(9.97+\log T_{c}-\log |\Delta| ; M\right.$. Hesse, H. Meier, B. Zeh, in Spektroskopische Methoden in der organischen Chemie, Georg Thieme Verlag Stuttgart, 1991, pp. 96.

23 A. Klamt and G. Schüürmann, J. Chem. Soc., Perkin Trans. 2, 1993, 799.

24 D. Nemcsok, K. Wichmann and G. Frenking, Organometallics, 2004, 23, 3640-3646.

25 C. Topf, C. Hirtenlehner, M. Zabel, M. List, M. Fleck and U. Monkowius, Organometallics, 2011, 30, 2755-2764.

26 G. Helgesson and S. Jagner, Inorg. Chem., 1991, 30, 2574.

27 (a) C. P. Newman, G. J. Clarkson and J. P. Rourke, J. Organomet. Chem., 2007, 692, 4962-4968; (b) H. M. J. Wang and I. J. B. Lin, Organometallics, 1998, 17, 972-975; (c) S. K. Schneider, W. A. Herrmann and E. Z. Herdtweck, Z. Anorg. Allg. Chem., 2003, 629, 2363-2370; (d) W. Huang, R. Zhang, G. Zou, J. Tang and J. Sun, J. Organomet. Chem., 2007, 692, 3804-3809; (e) J. Ye, X. Zhang, W. Chen and S. Shimada, Organometallics, 2008, 27, 4166-4172; $(f)$ D. J. Nielsen, K. J. Cavell, B. W. Skelton and A. H. White, Organometallics, 2006, 25, $4850-4856$.

28 (a) C. K. Lee, C. S. Vasam, T. W. Huang, H. M. J. Wang, R. Y. Yang, C. S. Lee and I. J. B. Lin, Organometallics, 2006, 25, 3768-3775.

29 R.-Y. Liau, T. Mathieson, A. Schier, R. J. F. Berger, N. Runeberg and H. Schmidbaur, Z. Naturforsch., 2002, 57b, 881889. 
30 U. Monkowius, M. Zabel and H. Yersin, Inorg. Chem. Commun., 2008, 11, 409-412 and references therein.

31 S. Attar, J. H. Nelson, W. H. Bearden, N. W. Alcock, L. Solujic and E. B. Milosavljevic, Polyhedron, 1991, 10, 1939-1949.

32 (a) P. Sinha, A. K. Wilson and M. A. Omary, J. Am. Chem. Soc., 2005, 127, 12488-12489; (b) Z. Assefa, R. J. Staples and J. P. Fackler, Jr., Acta Crystallogr., Sect. C: Cryst. Struct. Commun., 1996, 52, 305-307; (c) K. Angermaier, E. Zeller and H. Schmidbaur, J. Organomet. Chem., 1994, 472, 371-376; (d) U. M. Tripathi, A. Schier and H. Schmidbaur, $Z$. Naturforsch., 1998, 53b, 171-174; (e) G. A. Bowmaker, C. L. Brown, R. D. Hart, P. C. Healy, C. E. F. Rickard and A. H. White, J. Chem. Soc., Dalton Trans., 1999, 881-889.

33 H. Schmidaur and A. Schier, Chem. Soc. Rev., 2008, 37, 1931-1951.

34 X. Wang, S. Liu, L.-H. Wenig and G.-X. Jin, Organometallics, 2006, 25, 3565-3569.

35 M. A. Cinellu and G. Minghetti, Gold Bull., 2002, 35, 11-20; M. A Cinellu in Gold Chemistry, ed. F. Mohr, Wiley-VCH, Weinheim, 2009.

36 (a) H. Isci and W. R. Mason, Inorg. Chem., 1983, 22, 2266-2272; (b) W. R. Mason III. and H. B. Gray, Inorg. Chem., 1968, 7, 55-58; (c) W. R. Mason and H. B. Gray, J. Am. Chem. Soc., 1968, 90, 5721-5729.

37 T. J. Norman Jr., C. D. Grant, D. Magana, J. Z. Zhang, J. Liu, D. Cao, F Bridges and A. Van Buuren, J. Phys. Chem. B, 2002, 106, 7005-7012.

38 H. Mäuser, Z. Naturforschung, 1968, 23b, 1021.

39 The absorption maximum of bromine in DMSO is at $275 \mathrm{~nm}$ and quickly decreasing already without irradiation (see Fig. S20). This spectral region is also obscured by the absorption of the gold complex.

40 (a) C. Willis, R. A. Back, R. Corkum, R. D. McAlpine and F. K. McClusky, Chem. Phys. Lett., 1976, 38, 336-340; (b) D. Martin, A. Berger and R. Peschel, J. Prakt. Chem., 1970, 312, 683-689.

41 (a) O. Horváth and A. Vogler, Inorg. Chem., 1993, 32, 5485-5489; (b) H. Kunkely and A. Vogler, J. Organomet. Chem., 1998, 559, 223-225.

42 O. P. Studzinskii, A. L. Kartushanskii and B. T. Plachenov, Zh. Obs. Khim., 1985, 55, 673-676.

43 A. I. Popov and R. F. Swensen, J. Am. Chem. Soc., 1955, 77, 3724-3726.

44 P. de Frémont, N. Marion and S. P. Nolan, J. Organomet. Chem., 2009, 694, 551-560.
45 (a) D. Schneider, O. Schuster and H. Schmidbaur, Organometallics, 2005, 24, 3547-3551; (b) D. Schneider, A. Schier and H. Schmidbaur, Dalton Trans., 2004, 1995-2005.

46 Stoe IPDS-software, version 2.89, Stoe \& Cie GmbH, Darmstadt (Germany), 1998.

47 Nonius, Collect, Nonius BV, Delft (The Netherlands) 2003.

48 Z. Otwinowski and W. Minor in Methods in Enzymology, Vol. 276: Macromolecular Crystallography Part A (ed., C. W. Carter Jr. and R. M. Sweet), Academic Press, New York, 1997, 307-326.

49 G. M. Sheldrick, SHELXS-97, Program for the Solution of Crystal Structures, University of Göttingen, Göttingen (Germany), 1997.

50 A. Altomare, G. Cascarano, C. Giacovazzo and A. Guagliardi, J. Appl. Crystallogr., 1993, 26, 343.

51 G. M. Sheldrick, Shelxl-97, Program for crystal structure refinement, University of Göttingen, (Germany), 1997.

52 (a) R. Usón, A. Laguna and M. Laguna, Inorg. Synth., 1989, 26, 85; (b) B. P. Block, Inorg. Synth., 1953, 4, 16.

53 Turbomole V6.1, a development of Universität Karlsruhe (TH) and Forschungszentrum Karlsruhe GmbH, 1989-2007, and TURBOMOLE GmbH, since 2007. Available from http://www. turbomole.com, 2009.

54 R. Ahlrichs, M. Bär, M. Häser, H. Horn and C. Kölmel, Chem. Phys. Lett., 1989, 162, 165.

55 (a) A. D. Becke, Phys. Rev. A: At., Mol., Opt. Phys., 1988, 38, 3098; (b) J. P. Perdew, Phys. Rev. B, 1986, 33, 8822; (c) J. P. Perdew, Phys. Rev. $B, 1986,34,7406$.

56 F. Weigend and R. Ahlrichs, Phys. Chem. Chem. Phys., 2005, 7, 3297.

57 (a) J. Tao, J. P. Perdew, V. N. Staroverov and G. E. Scuseria, Phys. Rev. Lett., 2003, 91, 146401; (b) J. Tao, J. P. Perdew, V. N. Staroverov and G. E. Scuseria, Phys. Rev. Lett., 2004, 120, 6898-6911.

58 A. Hellweg, C. Hättig, S. Höfener and W. Klopper, Theor. Chem. Acc., 2007, 117, 587.

59 S. Patil, A. Deally, B. Gleeson, H. Müller-Bunz, F. Paradisi and M. Tacke, Appl. Organomet. Chem., 2010, 24, 781-793. 